Article

\title{
Five Practices for Building Local Capacity in Sustainability-Driven Entrepreneurship for Place-Based Transformations
}

\author{
Diele Lobo $^{1, *}$, Ana Carolina Rodriguez ${ }^{2}(\mathbb{D})$, Silvia Pereira de Castro Casa Nova ${ }^{3,4}(\mathbb{D}$ \\ and Alexandre A. Ardichvili ${ }^{2}$ (D)
}

check for

updates

Citation: Lobo, D.; Rodriguez, A.C.; Casa Nova, S.P.d.C.; Ardichvili, A.A. Five Practices for Building Local Capacity in Sustainability-Driven Entrepreneurship for Place-Based Transformations. Sustainability 2022, 14, 3027. https://doi.org/10.3390/ su14053027

Academic Editors: João Carlos

Correia Leitão and

Wadim Strielkowski

Received: 25 January 2022

Accepted: 22 February 2022

Published: 4 March 2022

Publisher's Note: MDPI stays neutral with regard to jurisdictional claims in published maps and institutional affiliations.

Copyright: (c) 2022 by the authors. Licensee MDPI, Basel, Switzerland. This article is an open access article distributed under the terms and conditions of the Creative Commons Attribution (CC BY) license (https:// creativecommons.org/licenses/by/ $4.0 /)$.
1 Department of Forest Resources, University of Minnesota, Saint Paul, MN 55108, USA

2 Department of Organizational Leadership, Policy, and Development, University of Minnesota, Minneapolis, MN 55455, USA; rodr0667@umn.edu (A.C.R.); ardic001@umn.edu (A.A.A.)

3 Accounting and Actuarial Science Department, University of São Paulo, São Paulo 05508-010, Brazil; silvianova@usp.br

4 Accounting Master Program, School of Business and Administration, Federal University of Mato Grosso do Sul, Campo Grande 79046-460, Brazil

* Correspondence: lobo0010@umn.edu

\begin{abstract}
There is a growing interest in how entrepreneurship animates deliberate sustainability transformations across societal levels. Few studies, however, have provided an empirically grounded account of practices employed by sustainability-driven entrepreneurial organizations for sustainability transformations. We address this gap by applying the critical Human Resource Development (CHRD) framework to identify practices for developing organizational and community capacity conducive to sustainability transformations in two cases of sustainability-driven entrepreneurship in the UNESCO World Heritage Site Serra da Capivara National Park, Brazil. We used case study methodology to identify five practices by conducting a reflexive thematic analysis with qualitative data from key informant interviews, documents, and secondary sources. Our results show that each practice was strongly oriented by relational values of care and social-ecological systems thinking. Both humans and nonhumans were taken as stakeholders who participate in and benefit from practices. Caring for the local place, place-based learning, and regenerative organizing appeared to be relevant for learning and development interventions that imparted significant changes in the local social-ecological context. We updated the CHRD framework to incorporate a nonhuman dimension and highlight caring, place-based learning, and regenerative organizing as essential areas of engagement in which HRD practices in support of place-based sustainability transformations occur.
\end{abstract}

Keywords: conservation entrepreneurship; social entrepreneurship; HRD practice; regenerative sustainability; care; biodiversity conservation; cultural heritage

\section{Introduction}

The need for transformative change in business-as-usual practices is a timely debate in both sustainability sciences and policy agendas [1]. A transformative approach requires the introduction and governance of bold, innovative changes focused on targeting the root causes - instead of the symptoms - of unsustainability and social inequalities that explicitly or implicitly guide the interactions in social-ecological systems [2] (underlined terms are defined in the Glossary (Box 1). Many of such root causes stem from a development path that privileges limitless economic growth, alienates humans from nature, and disregards power disparities at the expense of human wellbeing and the health of ecosystems [3]. Thus, initiating and governing deliberate transformations towards sustainability requires human agency capable of transforming social-ecological systems away from only pursuing economic growth towards ones that combine concerns over economic, environmental, and social—particularly power disparities—issues equally [3-5]. 
Sustainability-driven entrepreneurship is the process through which individuals or groups develop entrepreneurial opportunities to tackle social and environmental problems by leveraging economic activity that creates economic, social, and ecological value simultaneously [6]. Not surprisingly, sustainability-driven entrepreneurship appears increasingly attractive to articulate aspirations for deliberate transformations toward sustainability [7-12]. In support of these aspirations, social- and sustainability-driven entrepreneurship research has shed light on specific characteristics related to leadership, organizing models, and core innovations of such entrepreneurship forms that might enable their catalytic role in societal transformations as well as the mechanisms by which they operate [10,13-16]. For example, several social entrepreneurship initiatives with demonstrated potential for catalyzing high levels of social transformation (millions of people), such as BRAC, Grameen Bank, College Barefoot, and Gram Vikas, often have core innovations that mobilize and build on the assets of poor and marginalized groups as well as founders with the capacity to work with and build bridges among very diverse stakeholders [13]. In the context of low-carbon energy transition, the catalytic role of sustainability-driven entrepreneurship has been associated with the learning effects triggered by the introduction of novel business models that circumvent lock-ins of dominant technologies [7]. Lastly, several studies have associated the transformative effect of social- and sustainability-driven entrepreneurship to building capacities for self-care and conducive to sustainability behaviors within local communities and organizations [13,17-20]. Together, this research suggests that supporting the development of key capacities that enable the transformative potential of sustainability-driven entrepreneurial organizations is a potentially significant intervention point for promoting sustainability transformations [15,21]. Yet, little is known empirically about the practices employed by these organizations to develop such capacities within entrepreneurship and sustainability transformation literature [20].

One pivotal area of theory and practice for understanding and implementing practices for capacity building in organizations and communities is Human Resource Development (HRD), defined as a field "with a distinctive tripartite agenda of human betterment, organisational enhancement and societal development" [22] (p. 1). Traditionally, HRD practice involves varied learning, development, and change activities focused on individuals (e.g., skill training and career development), groups (e.g., team building and conflict management), and organizations (e.g., design of organizational strategies and culture change) for improving individual and organizational satisfaction and performance [22] The application of HRD principles and tools in sustainability-driven entrepreneurship to impart transformative changes towards sustainability is promising for at least two reasons. First, individual and organizational learning, development, and change-core strengths of HRD—are critical for sustainability transformations. Chan et al. [23] have proposed that change interventions in organizations to unleash latent values of environmental responsibility, raise awareness of social-ecological systems, and foster responsible innovations and investments are key levers for sustainability transformations. Second, HRD interventions have been found to play an important role in fostering positive sustainability and social changes in organizational and community settings [24-26]. However, depending on how practices are enacted, HRD interventions could reproduce rather than transform root causes of unsustainability [27]. As argued by Hestad et al. [20] (p. 7), "the processes and the groups of activities that the organisations engage in matter less than the rationales and practices of how they are implemented".

To advance a more fine-grained understanding of sustainability-driven entrepreneurship for place-based sustainability transformations, we employ a transdisciplinary approach to answer the following exploratory question: How do sustainability-oriented hybrid organizations engage with HRD practice to support the building of capacities conducive to fostering sustainability transformations at the organization and community level? Following Hestad et al. [15], we use the term sustainability-oriented hybrid organizations (hereafter, $\mathrm{SOHOs)}$ to refer to different types of profit and nonprofit organizations that engage in sustainability-driven entrepreneurship to solve social and environmental problems through 
holistic approaches. To answer our question, we used a qualitative case study methodology and the Critical Human Resource Development (CHRD) [28] to identify HRD practices of two $\mathrm{SOHOs}$ that have been widely acclaimed for promoting sustainability transformations in poverty-stricken rural communities surrounding the UNESCO World Heritage Site Serra da Capivara National Park, Brazil. In the CHRD framework, HRD practice consists of actions associated with relating, learning, changing, and organizing for enhancing individual and organizational capabilities and social impact [28]. The CHRD framework provides interrogatives to guide reflection on the context, stakeholders, values, assumptions, and methods of HRD practice and has been previously applied in studies of social inclusion in the workplace. To the best of our knowledge, this is the first study using the CHRD framework in the context of sustainability-driven entrepreneurship and community settings.

The two SOHOs, taken here as empirical and locally embedded cases, are (i) a notfor-profit scientific and non-governmental organization and (ii) a for-profit ceramic manufacturing company. The SOHOs operate within the broader social-ecological context of the backlands of Northeast Brazil, a semiarid region in which severe droughts, extreme poverty, long-standing clientelism, and weak institutions compound to increase the vulnerability of the poorest to environmental change $[29,30]$. By examining in detail the SOHOs' engagement in HRD practice within this context, the main contributions of this paper are three-fold: (1) advance theoretical understanding of deliberate sustainability transformations by bridging sustainability-driven entrepreneurship and HRD literature; (2) advance empirical case study research in sustainability-driven entrepreneurship and HRD in more heterogeneous and locally embedded contexts; and (3) inform practice in sustainability-driven entrepreneurship, HRD, and community development.

The paper proceeds as follows: First, we provide a conceptual foundation for the paper by (i) discussing the notion of sustainability transformations, (ii) summarizing relevant literature on the roles of sustainability-driven entrepreneurship and HRD for sustainability transformations, and (iii) outlining the CHRD framework. Then, we describe the study's research methods and characterize the $\mathrm{SOHOs}$ as well as their operating social-ecological systems. The empirical findings are then presented in the form of five HRD practices. The paper concludes with a discussion of key aspects of the HRD practices in support of sustainability-driven entrepreneurship and the proposal of an adapted CHRD framework deemed more beneficial for the context of transformative change toward sustainability.

Box 1. Glossary.

\begin{tabular}{ll}
\hline Care & "A species of activity that includes everything that we do to \\
& maintain, continue, and repair our world so that we can live in \\
& it as well as possible" [31] (p. 19). \\
Caring & Relating driven by a deep concern for and actionable \\
& commitment to the mutual flourishing of human and \\
& nonhuman stakeholders and systems [32]. \\
& "A difference within a person or between two or more people \\
Conflict & [or between groups of people] that touches them in a significant \\
& way" [33] (p. 12). Conflict often manifests itself in "expressed \\
& disagreements among people who see incompatible goals and \\
& potential interference in achieving these goals" [34] (p. 94). \\
& The "process of engaging human and organizational systems \\
that relate, learn, change, and organize in ways that optimize \\
human interest, organization advancement, and \\
Resource Development & social-ecological impact" [28] (p. 436). \\
& Intentionally bringing about fundamental changes in structural, \\
functional, relational, and cognitive aspects of social-ecological \\
Deliberate transformation \\
systems to enable the emergence of desirable futures [35].
\end{tabular}


Box 1. Cont.

\begin{tabular}{|c|c|}
\hline Entrepreneurial opportunity & $\begin{array}{l}\text { A possibility or situation to meet an unmet need, interest, or } \\
\text { want that creates new value or new possibilities through the } \\
\text { creative recombination of underutilized or unemployed } \\
\text { resources as well as capabilities [36]. Opportunities can be } \\
\text { discovered or created and can take different forms, including } \\
\text { new products, services, geographical markets, ways of } \\
\text { organizing, and norms, to name a few. }\end{array}$ \\
\hline Moral anger & $\begin{array}{l}\text { "An aroused emotional state stemming from a primary } \\
\text { appraisal of a moral standard violation that impacts others } \\
\text { more than oneself and prompts corrective behavior intended } \\
\text { to improve the social condition, even in the face of significant } \\
\text { personal risk" [37] (p. 743). }\end{array}$ \\
\hline Place-based learning & $\begin{array}{l}\text { "Experiential acquisition of knowledge, transformation of } \\
\text { perspectives, and building of skills through interaction with } \\
\text { local places and place-based knowledges" [38] (p. 458). }\end{array}$ \\
\hline Regenerative organizing & 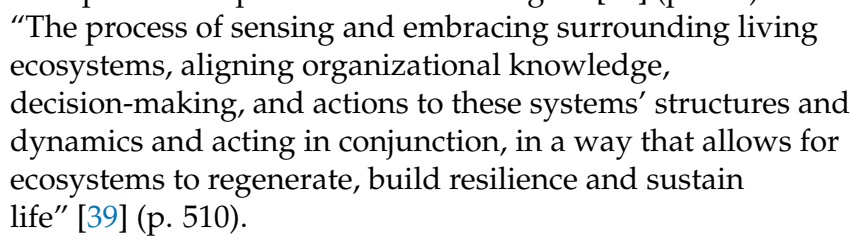 \\
\hline Regenerative workforce systems & $\begin{array}{l}\text { Network of public and private sector policies and programs } \\
\text { that provides integrated support services to help individuals } \\
\text { pursue opportunities for a sustainable livelihood and } \\
\text { organizations respond to the needs for continued functioning } \\
\text { and flourishing of social-technical-ecological systems [40]. }\end{array}$ \\
\hline Relation & $\begin{array}{l}\text { "A normative human sense of connection or kinship with } \\
\text { other living things, reflective and expressive of care, identity, } \\
\text { belonging and responsibility, and congruent with notions of } \\
\text { what it means to live a 'good life'" [41] (p. 1). }\end{array}$ \\
\hline Sense of place & $\begin{array}{l}\text { "The process by which individuals and groups derive } \\
\text { meanings, beliefs, symbols, values, and feelings from a } \\
\text { particular locality based on human experience, thoughts, } \\
\text { emotions, and social relationships" [42] (p. 40). }\end{array}$ \\
\hline Social-ecologica & $\begin{array}{l}\text { Complex adaptive systems in which humans are a part of } \\
\text { nature and human-nonhuman interactions shape and are } \\
\text { shaped by social and ecological structures [43]. }\end{array}$ \\
\hline $\begin{array}{l}\text { Social-ecological } \\
\text { systems thinking }\end{array}$ & $\begin{array}{l}\text { Holistic understanding of the dynamics of interlinked social } \\
\text { and environmental phenomena [43]. }\end{array}$ \\
\hline Stewardship & $\begin{array}{l}\text { "The active shaping of pathways of social and ecological } \\
\text { change for the benefit of ecosystems and society" [42] (p. 40). }\end{array}$ \\
\hline $\begin{array}{l}\text { Sustainability-driven } \\
\text { entrepreneurship }\end{array}$ & $\begin{array}{l}\text { The process through which individuals or groups develop } \\
\text { entrepreneurial opportunities to tackle social and } \\
\text { environmental problems by leveraging economic activity that } \\
\text { creates economic, social, and environmental } \\
\text { value simultaneously [14]. }\end{array}$ \\
\hline $\begin{array}{l}\text { Sustainability-oriented hybrid } \\
\text { organizations (SOHOs) }\end{array}$ & $\begin{array}{l}\text { "An organisation that applies business principles to solving } \\
\text { social and environmental problems and adopts holistic and } \\
\text { net positive sustainability as its primary logic" [15] (p. 654). }\end{array}$ \\
\hline
\end{tabular}

\section{Theoretical Background}

\subsection{The Notion of Sustainability Transformations}

The current global environmental crisis, alongside the very slow, or even negative, progress towards the goals set by several international treaties on environment and development, has led governments, civil society actors, and a growing number of scholars to turn their attention toward the notion of sustainability transformations $[1,23,44]$. These actors increasingly argue that incremental changes to the status quo alone are insufficient to match the scope and scale of today's human development challenges, and transformative 
changes have been deemed an urgent necessity [23]. In contemporary sustainability research, several notions of sustainability transformation emerged over the last decades from different disciplinary perspectives, including social-ecological systems, socio-technical transitions, environmental stewardship, adaptive governance, and transformative learning [4]. Broadly, transformation is generally understood as "fundamental changes in structural, functional, relational, and cognitive aspects of socio-technical-ecological systems that lead to new patterns of interactions and outcomes" [4] (p. 2). O'Brien [5] (p. 670) argues that transformation can also be understood as a "psycho-social process involving the unleashing of human potential to commit, care and effect change for a better life". Collectively, this scholarship offers three distinct but complementary approaches to understanding and acting on sustainability transformations [45]. The first focuses on the ways production and consumption are governed and organized in society (structural approach, e.g., debates on degrowth and circular economy) [45]. The second approach focuses on interdependencies between human and nonhuman entities within social-ecological systems or interactions between people and technology within socio-technical systems (systemic approach, e.g., debates on ecosystem-based adaptation and nature-based solutions) [45]. The third focuses on values, knowledge, agency, and other factors that affect the human capacity for self-help (enabling approach, e.g., debates on community capacity building and transdisciplinary co-production of knowledge) [45].

Sustainability transformations can be initiated either by external shocks or the actionsintended or unintended —of social actors [5]. When driven by intentional actions, sustainability transformation unfolds as a process by which social actors perform, in the face of uncertainty, to deliberately disrupt a dominant state that locks itself and social-ecological systems into an unfair and unsustainable pathway [5]. Much of the appeal of transformative change approaches lies in the assumption that deliberate transformations can be encouraged and achieved through radical shifts to current conditions or the accumulation of incremental changes over time [5]. Not surprisingly, calls and efforts to understand and support deliberate transformations have recently grown appreciably $[2,4,5]$. For example, transformative change is one of the three focuses of the Intergovernmental Science-Policy Platform on Biodiversity and Ecosystem Services (IPBES) 2019-2030 work program, and a transformative change assessment aimed at understanding and identifying factors in human society at both the individual and collective levels that may be leveraged to bring about transformative change has been commissioned by the IPBES 8 Plenary in June 2021 [23]. In this regard, scholars have identified several key leverage points (places to intervene in complex systems) to bring about, govern, and analyze transformative changes, including visions of good quality of life, relational values, power disparities, capacity building, knowledge co-production, responsible organizational action, and responsible technology, innovation, and investment [23].

\subsection{The Catalytic Role of Sustainability-Driven Entrepreneurship in Sustainability Transformations}

Entrepreneurship, as an economic and social phenomenon, is widely known for its potential to bring about creative destruction in markets-i.e., the radical replacement of dated economic structures and processes by new, more suitable ones-and societal transformations [13]. Scholars have argued that sustainability-driven entrepreneurship has the potential to act as a catalyst of sustainability transformations because it is a form of socio-economic agency consistent with the requirements of both transformative change and sustainable development $[7,9,10,15,46]$. Sustainability transformation involves systemic changes to problems that are uncertain and contested [4]. Entrepreneurial individuals or groups act in the face of ambiguity by accepting the risks associated with non-predictive actions and transforming uncertainty into opportunities to innovate [47]. York and Venkataraman [47] (p. 454) suggest that the key role of sustainability-driven entrepreneurs in regard to catalyzing deliberate transformations rests in the fact that "entrepreneurial action is driven by uncertainty rather than stymied by it" and "through this action, an alternative future is created rather than anticipated". 
Hestad et al. [15] (p. 657) argued that sustainability-driven entrepreneurial organizations are agents well-positioned to catalyze sustainability transformations because organizations "are where behaviours and technical solutions are realised, where social systems and institutions are reproduced or evolve, and where individuals enact discourses and paradigms". It is not surprising that high-impact entrepreneurial organizations, such as Grameen Bank and Native Energy, can transform social-technical-ecological systems from within $[7,13]$. Sustainability-oriented hybrid organizations (SOHOs) have been recently proposed as an umbrella concept to describe different types of entrepreneurial organizations that leverage market-related practices to solve social and environmental problems by introducing innovations [15]. SOHOs combine commercial, social, and environmental logics (i.e., belief systems that guide decision-making) and develop business models that help them navigate tensions that stem from pursuing the creation of economic, social, and environmental value together within market economies grounded on rigid dichotomies (e.g., nature vs. society, short-term vs. long-term returns) $[14,15,48]$. Broadly, SOHOs ${ }^{\prime}$ sought-after impact is to transform systems away from unsustainable practices, which is facilitated by the pursuit of a holistic and net-positive sustainability strategy (also discussed as nature positive or regenerative sustainability) [15]. Net-positive sustainability means that, instead of 'greening' existing practices by doing less harm (net-zero goals), SOHOs develop solutions to maintain or regenerate the quality of human and natural resources for the longest time possible [15].

In recent decades, a growing number of studies have explored what exactly makes social- and sustainability-driven entrepreneurship transformative. Many of such studies associate the catalyzing function of social- and sustainability-driven entrepreneurship with capacity building $[13,18,20]$. Hestad et al. [20] showed that $\mathrm{SOHOs}$ can foster sustainability transformations by building three essential transformative capacities within local communities, namely socio-ecological re-connection, fostering healthy individual and political agency, and building rich community relationships and social cohesion. Research on the characteristics of social- and sustainability-driven organizations and their leadership has identified a configuration of traits shared by SOHOs and their founding leaders, suggesting that developing such characteristics in organizations and individuals might foster engagement in and enhance the performance of such entrepreneurship initiatives $[13,14,49]$. For example, SOHOs are often founded by individuals with strong sustainability values and motives and moral commitment to enact those values [7,15]. At the organization level, Parrish [14] suggested the success of SOHOs in a competitive market context strongly depends on their capacity to use different principles of organizational design than the ones used by conventional enterprises. For example, by using the logic of resource perpetuation instead of resource exploitation to design the organization's purpose, entrepreneurs create enterprises as "a means of producing benefit streams through the perpetuation of resources" instead of "a means of profiting from the exploitation of resources" [14] (p. 517). Entrepreneurship scholars have theorized that these attributes may be central to the catalyzing effects of $\mathrm{SOHOs}$ because they can prompt the search for-or creation of-opportunities for solving social and sustainability problems, fuel a willingness to stray markedly from the status quo, and facilitate scaling up and sustaining impact $[7,13]$.

\subsection{The Supporting Role of Human Resource Development (HRD) Practice in Deliberate Sustainability Transformations}

Human resource development (HRD) is a relatively new field of practice and theory traditionally concerned with personnel training and development, career development, and organization development for performance improvement in corporate settings [22]. The supporting role of HRD practice in sustainability transformations is under-researched in HRD literature [50,51], even though the theme of transformation has long interested HRD scholars [52]. For example, transformational change and transformative learning theories have been used to discuss HRD contributions to helping organizations improve performance and implement changes to maintain a competitive advantage in markets [52]. 
More recently, several studies in HRD reported on successful applications of HRD principles and interventions for the general improvement of the welfare of people within and outside the workplace. McLean et al. [53] reported on the use of action research, needs assessment, leadership training, career development, financial counseling, and literacy training in support of community empowerment and poverty alleviation. Wang [54] identified HRD principles applied in successful social entrepreneurship initiatives tackling complex social and environmental problems, including health care, women's economic empowerment, poverty, and environmental degradation. In the context of environmental issues, Benton-Short and Cseh [55] discussed the role of HRD in improving crisis preparedness as a result of natural disasters and creating adaptive capacity for local leadership in urban sustainability planning. Sadler-Smith [56] outlined interventions with the potential to strengthen HRD's contributions to climate change mitigation and adaptation. Furthermore, conceptual approaches have been recently developed to offer a blueprint to strengthen HRD's supporting role in transformative change for societal development, including holistic HRD, green HRD, stakeholder-based HRD, and critical HRD $[25,28,57,58]$ Though these approaches are distinct in their central focus, there are often overlapping assumptions. A common assumption is that humanistic value-based approaches to HRD can enable its role as architect of transformative change toward equitable and sustainable organizations, communities, and nations $[25,27,28,59]$. Humanistic value-based approaches have been associated with HRD practice that (i) is guided by principles of ethics, responsibility, and sustainability; (ii) has human well-being as a core purpose; (iii) uses participatory approaches; (iv) raises critical awareness of power; (v) prioritizes stakeholders (over stockholders); and (vi) equally values the short-term and long-term outcomes [24,25,28,59,60]. A number of studies in sustainability literature have demonstrated that these characteristics are key requirements for successful transformative change initiatives $[3-5,23]$.

\subsection{The Critical Human Resource Development Framework (cHRD)}

The Critical Human Resource Development Framework is an analytical tool for understanding and implementing holistic and reflexive HRD practices [28]. It was built on critical theories and for providing operational definitions to help researchers and practitioners broaden their understanding of what HRD can and should be doing and engage in action informed by principles of critical HRD [28]. Critical HRD is a humanistic-based approach to HRD with the primary purpose of increasing "practitioners' critical awareness of power relations and their effects, as well as their capacity to act towards particular projects within these power relations" [61] (p. 116). Critical HRD core principles include transforming organizations toward a more equitable and sustainable state and opposing "the subjugation of human knowledge, skills, relationships, and education to organizational gain and goals that are primarily economic or instrumental" [62] (p. 198). This foundation makes the CHRD framework highly relevant to the study of sustainability-driven entrepreneurship for sustainability transformations because it cannot be assumed that innovation and change will not be met with resistance, especially when deeply held norms and values are questioned [3]. Moreover, equitable transformations require a deep commitment to acknowledging, questioning, and transforming power disparities, notions of good quality of life, and fallacies of limitless economic growth [3,4].

In the CHRD framework, HRD is defined as the "process of engaging human and organizational systems that relate, learn, change, and organize in ways that optimize human interest, organization advancement, and social impact" [28] (p. 436). Based on this definition, the CHRD framework structures HRD practice in four intersecting areas of engagement, namely relating, learning, organizing, and changing. Relating refers to the act of connecting with others. It "forms the context for learning, organizing, and changing" [28] (p. 437) because organizations ultimately exist in the relation between different roles and positions (social, temporal, and spatial) of stakeholders [24]. Learning refers to acquiring new understanding, knowledge, abilities, behavior, attitudes, and values at the individual and organizational level. Organizing can be understood as the act of structuring bundles of 
interactions, commonly associated with sense-making, designing, and coordinating. Thus, it accommodates spaces traditionally not thought of as niches of HRD practice within the field, such as social movements and community [53]. Lastly, changing refers to the act of making or becoming different and might result from planned or unplanned learning and organizing processes.

The CHRD framework uses four interrogatives to guide the analysis of practices within each area of engagement. The first guiding interrogative refers to 'context' and prompts reflection on where HRD interventions occur and what situational factors inform and influence them. The second refers to 'stakeholders' and prompts reflection on whom HRD interventions serve and who is privileged or marginalized by them. The third interrogative, labeled as 'process', prompts reflection on what values and assumptions undergird HRD interventions. Lastly, the fourth question refers to 'method' and prompts reflection on how HRD interventions are operationalized.

\section{Materials and Methods}

We used a qualitative case study approach to examine two cases of sustainabilitydriven entrepreneurship for biodiversity conservation and sustainable community development. Case study research is well-suited to studies focused on complex real-world issues as it allows for an in-depth, multi-faceted understanding of social-ecological phenomena in a real-life context [63]. Following Robert Stake's approach to case study research [64], we conducted an instrumental case study. The goal of an instrumental case study is to gain a broader understanding of a phenomenon or issue through an approach that foregrounds the phenomenon under investigation — rather than the case (e.g., a specific organization)-from start to finish [64]. An instrumental case study is based on a set of orientations that help researchers carry out qualitative studies on complex issues in a real-life context. These orientations include taking cases as a set of interrelationships between the phenomenon under investigation and its empirical context, privileging field observations in analyses, grounding data collection and interpretation of findings on the research participants' subjective experiences and feelings, and accounting for the importance of subjectivity of interpretations as well as researcher-subject interactions in qualitative studies [63]. Another important aspect of Stake's approach to qualitative case study is its strong emphasis on the need for a flexible procedure to data collection and analysis that allows for incorporating new sources of data and different techniques [63]. We adopted an instrumental case study approach given our primary focus on understanding deliberate sustainability transformations in a multi-stakeholder and contested context, where intertwined and multifaceted aspects of social and ecological systems require holistic and interdisciplinary approaches to research.

\subsection{Study Site and Case Study Description}

The cases selected for this study are two SOHOs whose efforts for coupling natural and cultural heritage conservation and livelihoods have fundamentally transformed their operating place [65,66]. We selected these organizations because (1) their social-ecological context provided us "a textbook example" of sustainability issues facing deprived rural communities and SOHOs in developing economies; (2) the organizations' long history provided us with longitudinal data, which allowed for an understanding of the longterm impact of practices; (3) the transformational impact of their work have been widely recognized as successful nationally and internationally and well-documented in academic literature and mass media, which enabled greater access to information; and (4) the first author's familiarity with the broader social-ecological context, including the region's natural history, culture, and language allowed a nuanced interpretation of practices.

The SOHOs are connected to and headquartered in communities near the Serra da Capivara National Park (hereafter, SCNP). The SCNP is a federal protected area located in the southeastern part of Piauí, Northeast Brazil, and was created in 1979 to protect the region's astonishing and well-preserved biodiversity, landscape, and testimony of pre- 
historic Amerindians, for which it was designated a Cultural Heritage Site by UNESCO in 1991. Over 1200 archaeological sites - each with numerous prehistoric rock paintings-are documented within and around the SCNP, making it the region with the largest concentration of rock paintings currently known in the Americas [65]. The SCNP is embedded in the social-ecological context of the Caatinga, a semi-arid region located in its entirety within Brazil's hinterlands. The Caatinga is the largest and most biodiverse seasonally dry tropical forest in the world, with about $33 \%$ of its population living in small rural villages, and most of them have relied on rain-fed subsistence agriculture and the extraction of regional natural resources to make ends meet [67]. In the SCNP region (i.e., municipalities around the Heritage Site) and the Caatinga at large, acute and chronic human disturbances (e.g., wildlife poaching and forest loss and fragmentation) have led to a rapid transformation of the local ecosystems, resulting in significant losses of their life-supporting capacities [67]. Moreover, the intricate nexus among poverty, poor infrastructures, long-standing political clientelism, and increasing climate impacts has been increasing the vulnerability of local ecosystems and their people to threats from environmental changes, including droughts, desertification, and deforestation [29,30].

The first case is the non-governmental organization Fundação Museu do Homem Americano (hereafter, FUMDHAM), founded in 1986 by a female Brazilian researcher and her research team who have worked in the SCNP region since 1970. It was this research team that petitioned Brazil's government for the creation of a protected area in the region. FUMDHAM's mission, as written in its statutes, is to return to society the results of the research in the cultural and ecological field as well as the social-economic development in the protected area. In practice, this mission primarily translates into operationalizing natural resources management and conservation actions within the SCNP, conducting multidisciplinary research, developing the local workforce, and promoting sustainable heritage tourism. Since its early years, FUMDHAM has managed the SCNP in partnership with Brazil's environmental agency charged with conserving and managing the country's protected areas (currently, the Chico Mendes Institute for Biodiversity Conservation-ICMBio). FUMDHAM owns and manages two museums and a research center equipped with laboratories, archeological and paleontological collections, and a library (see Appendix A for an overview of the organization's history, structure, activities, and revenue stream model). Most of FUMDHAM's entrepreneurial work centers on bringing about new geographical markets based on sustainable heritage tourism and conservation by developing the local workforce, building place-based enterprises, and creating and bridging institutional arrangements among stakeholders across sectors. Some of the interventions implemented by FUMDHAM for developing local human resources are creating schools and providing education for local children and adults, creating career development and vocational training opportunities, creating a gender-responsive labor policy to increase local women's participation in the labor market, and financing the creation of community-based enterprises [65].

Our second case is a for-profit company (hereafter, Ceramics Enterprise) formally created in 2005 by a newcomer female entrepreneur with significant experience in business management in corporate settings. The Ceramics Enterprise's primary activity is artisan ceramic manufacturing. Later, the business expanded to incorporate hospitality services-a restaurant, hostel, and clothing store. The Ceramics Enterprise's mission is to produce high-quality ceramic dinnerware that promotes the local cultural heritage and sustainability values for the benefit of the SCNP and its surrounding communities. The company has six small ceramic shops, one factory, one restaurant, one hostel, and a clothing shop. Some of its interventions for developing human resources are skills training, implementing social contracts with workers, profit sharing, and employee advocacy [68] (see Appendix A).

\subsection{Data Collection}

Data were collected from interviews and secondary sources between 2017 and 2021 (Table 1, see Appendix B for a complete data list). We conducted 60 semi-structured interviews in Brazilian Portuguese (participants' language) with four groups of informants: 
(1) founders, (2) top management team members, (3) current employees, and (4) nonemployees from the local community. Interviews lasted on average $60 \mathrm{~min}$ and were conducted in person during two field visits and virtually through video calls. Interviewees provided either written or verbal consent to participate in the study.

Table 1. Summary of the collected data.

\begin{tabular}{ccc}
\hline Data Source & Data & Alias * \\
\hline Interview & $\begin{array}{c}\text { Founders 2017-2018 } \times 3\left(\mathrm{C}^{*}\right), 3\left(\mathrm{~F}^{*}\right) \\
\text { Top management team members 2017-2021 } \times 7(\mathrm{~F}) \\
\text { Employees 2017-2018 } \times 4(\mathrm{C}), 20(\mathrm{~F}) \\
\text { Non-employees 2017-2018 } \times 27\end{array}$ & $\begin{array}{c}\text { Int. CF, Int. FF } \\
\text { Int. TM } \\
\text { Int. CE, Int. FE } \\
\text { Int. NE }\end{array}$ \\
\hline Archive & $\begin{array}{c}\text { Organization documents 1990-2011 } \times 49(\mathrm{~F}) \\
\text { News media (newspaper, magazine articles, video } \\
\text { interviews) and film documentaries } \times 15(\mathrm{C}), 37(\mathrm{~F})\end{array}$ & Doc. \\
1990-2021 & $\mathrm{Nm}$. \\
${ }^{*}$ C refers to Ceramics Enterprise and F to FUMDHAM. Alias refers to the code used to report data in the Section 4.
\end{tabular}

Two strategies of purposeful sampling were used to collect interview data: snowball and maximum variation. These strategies were used to facilitate access to key informants (snowball) and ensure a mix of informants with different experiences with the SOHOs (e.g., maximum variation; different occupations, knowledge, engagement, and perspectives on the SOHO's activities). We first conducted one exploratory interview with each founder to understand the organization's mission, values, history, core strategy, and changes over the years. In two follow-up interviews, we focused on decisions and actions related to organizational and workforce development, asking questions about the assumptions and reasons for adopting certain strategies, stakeholders, the methods implemented, and the perceived or observed impacts on both the organization and local social-ecological systems. We also asked questions about personal history and held values, motivations, and meanings attached to sustainability, conservation, and the local place. Repeated interviews with the founders in successive periods allowed us to clarify points and corroborate key preliminary findings. Interviews with top management team members used a similar approach but focused on their specific roles within the organizations. This group consists of people with current or past leadership or managerial positions in FUMDHAM. Interviews with employees and non-employees asked questions regarding their engagement with the SOHOs and views on changes in personal beliefs, community life, and the natural environment as a result of the SOHOs activities. All informants in the employee group are locals. Non-employees consisted of people who the organizations did not employ during data collection. Most of them were direct or indirect beneficiaries of FUMDHAM's interventions (e.g., participated in a training program or a parent is an employee). Most of the informants in the employee and non-employee groups are residents of the two rural villages that benefited the most from the SOHOs' activities.

Secondary data were collected from online sources, including video interviews, documentaries, newspapers, magazines articles, scholarly works, and FUMDHAM's archives, including strategic plans, annual reports, and projects. We collected 147 documents. See data availability statement for data access.

\subsection{Data Analysis}

Raw data were collated into a single database in the qualitative data analysis software MAXQDA@, sorted and named according to data sources, and cataloged in a data list with unique identifiers to provide an audit trail.

To identify HRD practices, we conducted a reflexive thematic analysis using a six-phase approach [69] and applied the CHRD framework [28]. The phases are (1) familiarization 
with the data, (2) generating codes, (3) constructing themes, (4) revising themes, (5) defining themes, and (6) producing the report.

In phase One, we familiarized ourselves with the data by reading all the materials repeatedly and scoping for information that allows us to establish a comprehensive overview of each SOHOs' purpose, functioning, and history, the characteristics of their operating social-ecological systems, and the occurrence of events that led to changes to both. During this phase, we held team meetings to establish a common understanding and discuss features of organizational strategies and interventions. Following the familiarization phase, we used interview transcripts and documents as the primary data sources for analysis, which consisted of generating codes. Other archival data were used to supplement and validate interviews and documents. We first produced initial codes by reading, labeling, and indexing datum (i.e., segments of texts) with information that answered the four guiding interrogatives of the CHRD framework. These interrogatives prompted codes associated with situational factors, stakeholders, values, and assumptions underpinning HRD practice as well as methods of implementation (see Appendix $C$ for code list). We used a semantic approach to coding as much as possible, i.e., the codes related to what a participant has said or was written in a document (i.e., explicit or surface meanings of a segment of data). Latent codes (underlying meanings) were assigned to values and assumptions.

Phases Three, Four, and Five formed the basis for identifying HRD practices and were undertaken deductively by drawing on constructs of the CHRD framework and relevant literature. These phases were conducted through an iterative and reflexive analytical process by which the researchers discussed the coded data over the course of ten team meetings. In Phase Three, we generated potential themes by recognizing regularities (patterns) in the coded data regarding the SOHOs' actions associated with the four areas of HRD engagement: relating, learning, changing, and organizing. Here, a theme refers to a gerund phrase that brings identity and meaning to a recognized pattern. To name the themes, we relied on the research team's disciplinary expertise (conservation science, entrepreneurship, and HRD) and drew from theoretical constructs that the recognized patterns were representative thereof (see glossary). In Phase Four, we zoomed in on each potential theme to assess its coherence by finding and discussing data that supported or contradicted them. In Phase Five, we zoomed out to assess the distinctiveness of the themes. During this phase, themes were combined and renamed to reflect the recognized patterns in the whole dataset in a meaningful and distinct manner. We then generated a list of final themes-the HRD practices-through this analytical process after consensus was reached among all researchers. Lastly, phase six—producing the report—served "as a final test of how well the themes work, individually in relation to the dataset, and overall" [69] (p. 857). We re-ordered the themes to improve the findings' logical coherence and story when writing the report. Though described herein in a linear fashion, Phases Three to Five were carried out iteratively.

\section{Results}

We identified five HRD practices that enabled the SOHOs to support the building of capacities conducive to fostering sustainability transformations at the organization and community level. Each of these practices was related to multiple areas of HRD engagement, reflecting their closely interlinked nature. We found that design and implementation choices in HRD interventions made by the founders and top management team members were guided by values of responsibility, reciprocity, solidarity, kinship, trust, social inclusion, stewardship, and work ethics. With respect to assumptions underpinning HRD interventions, we found that these informants consistently reported holistic and integrated approaches, transdisciplinarity, collaboration, long-term commitment, continuity, recognition of the multiple values of nature, and embeddedness in place as foundational to any intervention. When asked about situational factors that have influenced HRD interventions, founders reported different aspects of the local place, including ecological disequilibrium, droughts, landscape aesthetics, rock art, livelihood vulnerability, poverty, 
education and health, physical and social infrastructure, workforce and employment, local knowledge, social conflicts, political relations, and mindsets. Concerning stakeholders, humans and nonhumans were reported as participants and beneficiaries of interventions. Human stakeholders involved groups from different sectors (e.g., government, business, and universities) and jurisdictions (local to international). The primary beneficiaries of interventions were the SCNP (biodiversity and rock art) and its neighboring rural communities, especially the most vulnerable people and children. Researchers, tourists, and prehistoric and future generations were also important stakeholders.

The HRD practices are summarized in Table 2 and elaborated below. Some illustrative examples and quotes are provided to demonstrate the practices in specific situations and give a vivid representation of the patterns derived from data analysis. The quotes are followed by a code that indicates their source, as presented in Table 1.

Table 2. Five practices for building local capacity employed by two sustainability-driven entrepreneurial organizations fostering sustainability transformations in the UNESCO World Heritage Site Serra da Capivara National Park, Brazil.

\section{Practice and Description}

1. Using social-ecological systems thinking to develop core strategies that embody transformative changes.

Social-ecological systems thinking might enable practitioners to make sense of operating places as configurations of ever-evolving interdependencies between humans and nonhumans and envision possibilities for creating a new integrated system with reciprocal feedbacks and interdependencies.
Representative Data

1.1. The local population survives thanks to small agricultural activities, whose profitability is variable because it is a region within the drought polygon. The income obtained is insufficient, especially during periods of prolonged drought. Due to this situation, the local people are forced to practice activities that introduce environmental disequilibria, such as predatory hunting, the extraction of wood, and limestone mining. (Doc. 5)

1.2. The thing is knowing the region well. First, the situation of the misery of the population was terrible. A complete lack of schools, lack of hospitals, lack of doctors, there was nothing here. So, the idea was we could take advantage of this Park, the beauty of the landscape, archeology, and research to try to change that. So, we did a study with technicians from the Inter-American Development Bank that showed that agriculture and animal husbandry would never yield financial results in the region because of the soil and climate but that it had a huge tourist potential, and we were advised to invest and develop tourism. (Int. FF)

1.3. The development of FUMDHAM in Serra da Capivara initially faced the challenge of lack of awareness among the local communities about the outstanding universal value of the World Heritage site and its relevance for local community development (Sw. 33)

1.4. For burning with gas, the [Ceramics Enterprise] makes a difference for everyone, for history, for the people who live around it, for the country, for Piauí itself. We know that the cost of the gas is 50\% [of the company's budget], right? But we never considered replacing it [for firewood], even though this investment is nuts because firewood will likely come from illegal deforestation, and this is a major problem in our region. (Int. CF) 
Table 2. Cont.

\section{Practice and Description}

2. Organizing new institutional arrangements across sectors to develop regenerative workforce systems.

Brokering institutional arrangements across public and private sectors and jurisdictions to bring about regenerative workforce systems might enable practitioners to transform production systems away from an exploitative modus operandi.

This transformation is enabled by creating an integrated set of policies, programs, and organizations that ensure a skilled workforce exists to support the sustainable and equitable economy as well as secure life-long employability in a rapidly changing world, particularly for the most vulnerable groups.

3. Using place-based learning to foster sense of place and long-term stewardship.

Promoting learning about (content), in (physical space), from (source of experiences), with (experience of collaboration), and for (broader and meaningful purpose) the local place might enable practitioners to transform local organizations and workforce away from existing exploitative practices and unleash relational values of care for the local place.

\section{Representative Data}

2.1. The amount of institutions and professionals involved, as well as the continuity of the [FUMDHAM's] work, is difficult to match anywhere else within Brazil. This effort accounted for very distinctive improvements in the villagers' ways of living, educational and health standards, and citizenship, not found in the neighboring regions outside the influence area of the project. (Sw. 14)

2.2. The [workforce education and training] projects must be conceived in a way to embody the dynamics of the transformation towards a more harmonious coexistence between humans and nonhumans and between humans and the environment. (Doc. 27)

2.3. Environmental education intends to leave its mark on the basic educational cycle, enabling the understanding of the relationship between social life and the environment. It offers essential tools to [the children] formulate a life project in balance with the dynamics of the natural environment and to leave the primary cycle with career and vocational options that allow a harmonious development of the productive activity with the environment. (Doc. 4)

2.4. The final product we are looking for is an adolescent who graduates primary school with basic education and technical training to develop professional activities that guarantee a reasonable income. The technical education offered is diversified. There are two main vocational areas. Those specifically linked to the national park, rock paintings conservation, field research, and ecotourism. Those connected with sustainable, productive activities, including honey production and other bee products, handicraft, pottery, and paper recycling. (Doc. 27)

3.1. Our idea was really to work in a contextualized way, right? We would deliver classes for the teachers at the Boqueirão da Pedra Furada [area within the National Park]. Then, the teachers would do the same [with the children] ... We had children as young as five years old writing "iguana" [a reptile]! Because she [the teacher] would get the iguana for them [students]. She would get the wild animals from nature, walk with them [students] in the woods. (Int. TM3)

3.2. I remember that we once used a book from outside, and the teacher said, "Oh, this poor boy who lives in a favela [slum], he must be full of scratches, all bruised." I thought, "what is going on inside this woman's head to tell me this?" But I was the ignorant of the situation because the only favela they [local people] knew about was a tree with thorns that scratched them. I was the ignorant one in the contextual relation of the textbook, right? (Int. TM3)

3.3. From the moment I started working inside [the National Park], I had the opportunity to see stunning scenes like a tegu [lizard] entering its nest every day, until the day the offspring would come out. Seeing this every day, I became more and more delighted. It was very difficult to see a collared peccary [mammal], and over the years that I have been working inside the park, I get there and feel very proud to see something that I saw once in my lifetime. And now, I see it often. So, I understand that the work I develop [tour guide] is helping this in a certain way. (Int. NE1)

3.4. You see, people [Ceramics Enterprise's employees] draw, reproduce the rock paintings on a ceramic piece. With the perfection that they do, they must really like and be very proud of what they do. (Nm. 11) 
Table 2. Cont.

\section{Practice and Description}

4. Embracing conflict as a social resource to organizational development.

Embracing conflict-particularly social conflict-rather than ignoring or avoiding it might facilitate learning of different perspectives that cause disagreements and unproductive outcomes. Taking this learning seriously might help practitioners employ existing or create new strategies and assessment tools to support the development of places towards more equitable, democratic, and sustainable paths.

\section{Representative Data}

4.1. Men drink a lot here; we had domestic violence problems [ . . . ] Gosh, I think this was one of the worst situations I went through. You start to do the work of Mother Teresa of Calcutta, but you are not psychologically prepared for it, you know? [ ... ] This was very tough because you had your employees arrested on the weekend, and, on Monday, you would go there [police station] and ask for them to be released [ ... ] All of this is learning. It is day to day. I first thought it would be extremely easy [managing the company], but it was tough. (Int. CF)

4.2. What is happening to us now doesn't happen anywhere. Suddenly someone decided that we were in the mining sector. We spent about two years spending what we had and what we didn't have to adapt [to the sector's regulations]. Now, the Union of Industry and Commerce of Piauí decided that we are an industry and more, that we have to equalize the wages of our artisans, which is a minimum wage, with the salaries of the other companies in industry and commerce in the state, which have an industrial production! (Int. CF)

4.3. A dialogue between them [FF and a poacher] started. He said, "Why don't you do the same thing with our children? Create the conditions so that our children can live here with proper conditions?" ... and so, it began. We came back [to the main office] ... and [FF] had this idea to start this work [schooling program], which you can't do in two years. It is not just a project for one government administration. It is a succession of years. You must reach several generations (Sw. 17)

4.4. FUMDHAM realized that the rate of violence against women here in the countryside is very high. We have already dealt with and helped in situations with our own employees, who arrived completely hurt [ ... ] FUMDHAM held one seminar here about the valorization of women, you know, gender. It even brought deputies and police officers from Spain to train and talk with the deputies and police officers from here about how to help women in cases of violence. Also, it set up a support center for battered women. (Int. TM2)

5.1. Then, one day, she [FF] came here and said, "I'm no longer employing men! I will hire only women because I'm sure they will use their earnings to buy food for their children." Then I know that out of 100 women, 70 were hired ... Then, the work was excellent. But [FF]'s idea was to reverse the picture. It was for the woman to go to work and the man to stay at home so that he could understand [traditional] women's work. (Int. TM1)

5.2. Geez! Go and say that it was the guy [artisan employee] who made it! and not say: "Ah, I'm a [Ceramics Enteprise's] designer." Well, if you are a [Ceramics Enterprise's] designer, you would have been here since it was founded! So, I think this is not fair, you know? We always have had this problem with designers because of this. But we need those people. So now I tell them right away: "Whose name will you use to sign the piece." (Int. CF)

5.3. FF said on the news that she was going to close the park because of the lack of funds. She can't close the Park! It's not under her purview to do that. But a word from her mouth influences a thousand situations. It even caused conflicts with those who support FUMDHAM because it messes with the economic situation of the whole thing here. How many booked trips were canceled last year because of this? I had several cancellations. (Int. NE11)

5.4. One of the biggest battles we had was against the caieiros (limestone quarry's workers), who destroyed the rock paintings and broke everything to make lime. Today, and this is an interesting thing, one of the sons of a quarry's owner works in the Park. He told a researcher, a friend of mine, that he has now realized that FF was fighting against him for him. Isn't this amazing! I mean, it was for his wellbeing that she did all that work, that fight, that war against limestone mining. (Int. TM2) 
Practice 1: Using social-ecological systems thinking to develop core strategies that embody transformative changes.

Social-ecological systems thinking formed the basis for actions associated with relating. In our dataset, social-ecological systems thinking was primarily represented by the founders' and top management team members' deep understanding of the interdependencies of the local social and ecological systems as well as considerations of social and ecological feedback loops in planning actions associated with learning, organizing, and changing (Int. CF, FF, TM1-7, Table 2, 1.1).

Social-ecological systems thinking facilitated learning about threats and potentialities of the local place that were further developed into new products, services, and markets adapted to the local ecological and cultural settings (Table 2, 1.2). Local knowledge of pottery is an example of such a potentiality, as explained by an informant: "the ceramic technique started to be taught at the [FUMDHAM's] schools. The students started to learn with the elders, who knew how to do it, with those families that had all the knowledge of preparing [the clay]" (Int. TM1). Social-ecological systems thinking also facilitated learning about how the SOHO's performance was linked to indirect drivers of unsustainability, including poor education and health, poor infrastructure, and gender violence. Relating performance to such drivers led to the understanding of core strategies that accounted for fundamental changes to the infrastructural, relational, and cognitive aspects of the local place (Table 2,1.3). This is clearly articulated in many of FUMDHAM's documents: "the necessity to introduce radical changes became evident in the face of the institutional and operational difficulties of the Serra da Capivara" (Doc. 34). In practice, accounting for fundamental changes led to actions that often defied local business-as-usual practices and social norms while foregrounding the unmet needs of the local community. For example, the high financial costs of natural gas did not dissuade Ceramics Enterprise's founder from substituting it for firewood, a cheaper and widely used source of energy by the manufacturing companies in the region (Table 2, 1.4).

Practice 2: Organizing new institutional arrangements across sectors to develop a regenerative workforce system.

Workforce development was a core concern of both SOHOs (Int. FF, CF, TM1-7). Workforce development interventions were recurrently implemented by brokering new institutional arrangements and partnerships across sectors (including universities, development agencies, corporations, NGOs, and governments), jurisdictions (local to global), and professionals across disciplines. The SOHOs succeeded in bringing about high-impact workforce development interventions by brokering new institutional arrangements that leveraged the commitments of resourceful institutions and professionals (Table 2, 2.1).

Data about workforce development revealed that investments in human capital and support services sought to enable the emergence of local workforce systems capable of regenerating rather than degrading human and natural resources in a reciprocal way (Int. FF, TM1-7). In both cases, developing the local workforce meant re-establishing and sustaining harmonious relations between cultural heritage, environment, and population (Table 2, 2.2). We also found that workforce development centered on holistic approaches and strengthening connectedness with the place-cognitive, physical, and material. FUMDHAM's workforce development efforts were guided by the assumption that the local community "needed to go back to doing what prehistoric man did. Living in harmony with nature, respecting biodiversity, thus ensuring the continuity of natural resources, a necessary source for our survival" (Doc. 27). Based on this, FUMDHAM designed and implemented an innovative workforce development program in which principles and practices of environmental education interweaved with general and technical education (Table 2, 2.3). Raising awareness of the instrumental and symbolic values of the SCNP was assumed to be important to the local community to envision possibilities of decent work and sustainable livelihoods locally without resorting to temporary labor migration, a serious intergenerational social problem in the region (Int. FF, Doc. 4-7, 11-13, 21-28). Additionally, diversifying careers and jobs that benefited greatly from a well-conserved SCNP 
and local investments in research were assumed to be important to secure the perpetuity of the SCNP alongside economic security in a region where climate change is worsening livelihood vulnerability (Table 2, 2.4). The same logic drove FUMDHAM's investments in community-based enterprises based on productive activities well-adapted to the local ecosystem and climate, including honey production, snake venom production, and wildlife farming. Both the current and future workforce were taken as beneficiaries of workforce development interventions in the case of FUMDHAM, though the latter (children and adolescents) was the primary beneficiary. In the case of Ceramics Enterprise, employee training and development involved training for upgrading the quality of the products and services as well as opportunities to nurture career identity-seeing oneself as an artisan as opposed to a factory worker (Int. CF). These opportunities included organizing partnerships with external designers and organizations where the ceramic pieces and the artisans were promoted together.

Practice 3: Using place-based learning to foster a sense of place and long-term stewardship.

Learning activities leveraged place-based resources, both material and symbolic (e.g., rock paintings, SCNP, and local knowledge), as stimuli for engaging the current and future workforce in learning activities (Int. FF, Int. TM1-6, Doc. 4, 27, Sw. 5, 8). The local place was leveraged as a source of information for developing a culturally sensitive and relevant curriculum, a stage where learning activities took place, an interactive element in experiential learning, and a purpose for learning (Table 2, 3.1 and 3.2). The underlying assumption was that by using place-based resources-including place meanings-to develop learning activities, the desire to belong to, be aware of the values of, and care for the local place would flourish (Int. TM3, Doc. 4, 27). These assumptions oriented the design and implementation choices of both general and technical education programs. This pattern emerged more clearly in the case of FUMDHAM, whose education program set as a core objective "to develop a sense of individual responsibility in relation to oneself and one's context, creating the possibility for each person to have the capacity to identify real environmental problems, evaluate them, and take the necessary actions to solve them" (Doc. 27). Deep knowledge of and appreciation for local nature and prehistoric people was important to the SOHOs in many ways, including a sense of purpose and source of innovation and creativity (Int. FF, CF, TM3, 6). As stated by the Ceramics Enterprise's founder, "each person who buys our ceramic pieces is buying a piece of our history. So, this is what we do; that is what we promote" (Nm. 11).

Experiential learning was particularly important in constructing a sense of meaningful work (Int. CF, FF, TM1-7, FE1-15, CE1). Learning unfolded through observing and engaging with human-nonhuman and human-human interactions. Most informants reported that everyday interactions with wildlife, rock paintings, and landscapes contributed to a deeper recognition of the importance of their work (Table 2, 3.3 and 3.4). Guided tours in the ceramic factory, in which employees share information about their work and the SOHO's and Park's history with tourists, were reported as a factor that has contributed to the development of a deeper appreciation for their place and personal satisfaction among employees (Int. CF, EC1). Founders and top management team members also reported the importance of learning from and with the local people for personal and organizational development (Int. CF, FF, TM1-8). As stated by one informant, "becoming integrated with the environment, with nature and people, it gives you a ... a ... meaning. This knowledge of nature, the environment, the place, this was one of the things I learned from the people here" (Int. TM2).

Practice 4: Embracing conflict as a social resource to organizational development.

Conflict, particularly social conflict, was at the core of the SOHOs' functioning and the main driver of actions associated with learning, organizing, and changing within and around the organizations. Data triangulation revealed that conflict was a constant rather than an episodic element shaping the SOHO's venturing trajectory (Sw. 2, 3, 11, 25, 35, 41). In the case of the Ceramics Enterprise, conflict was evident in data referring to living up to the enterprise's commitment to sustaining its social mission in its day-to-day operations (Int. 
$\mathrm{CF})$. The Ceramics Enterprise's founder articulated that her extensive corporate experience offered little - and often conflicting - knowledge on how to ethically lead and manage the social enterprise within the local social and cultural context, particularly in terms of relationships with internal and external stakeholders: "everything that exists here works differently from what you learned in college or your work elsewhere, right? You know that [normative] thing: "You have to." No! Here it's the opposite of everything else. You deal with people; you have to make them understand [company's work and social context]" (Int. CF). A particularly challenging matter was upholding the organization's supportive role to employees whose off-duty conduct-in the case recounted, related to alcoholism and gender violence-directly conflicted with the enterprise's commitment to promoting women's empowerment (Table 2, 4.1). Likewise, the relationship between the company and regulatory agencies is a source of conflict due to the unfitness of the existing regulative and normative institutional structures to regulate adequately sustainability-driven, place-based enterprises like the Ceramics Enterprise (Table 2, 4.2).

FUMDHAM took conflicts with and among stakeholders seriously by acknowledging their existence and designing innovative organizational strategies to create a shared purpose and mutually supportive relations between the organization, the SCNP, and stakeholders (Int. FF, TM1-7). A foundational step of FUMDHAM's planning process was identifying the competing needs of local stakeholders (humans and nonhumans) and their abilities (or lack thereof) to respond to these needs (Int. FF, TM1-7, Doc. 19). A number of social innovations in the forms of education, employment, and entrepreneurship programs, as well as institutional arrangements, arose from this process (Table 2, 4.3 and 4.4), including the community support centers, gender-responsive labor policy, nature-based enterprises and markets, and domestic violence support services. Embracing conflicts in planning processes also led to higher-level organizational changes, such as reshaping organizational function (Int. FF, TM1-7). During its early years, FUMDHAM expanded its original purpose-production and promotion of scientific knowledge and support to the management of the SCNP - to include a deeper engagement with the day-to-day operational management of the SCNP and entrepreneurial activities (Int. FF, NE8).

Practice 5: Embracing moral anger as an affective resource to transformative change. Embracing moral anger was a dominant theme connected to actions intended to lessen harm inflicted on others (humans and nonhumans) due to perceived wrongdoings, including domestic violence, impunity against criminal activity, and embezzlement (Int. $\mathrm{CF}, \mathrm{FF}, \mathrm{TM} 1-7)$. We found that moral anger was an important trigger of responsive actions to perceived wrongdoings that lead to radical changes within the organization and the wider community. When asked about transformative changes within the local community, informants talked about the SOHOs' gender-responsive labor policies and investments (Int. CF, FF, TM1-8, CE1-4, FE1-20, NE2-7,12,13,15). Informants consistently associated these interventions with tangible and long-lasting positive changes to women's social status as well as family welfare in their communities. In their accounts of the FUMDHAM's genderresponsive labor policy, the founder's indignation about the violence facing local women and her increasing dissatisfaction with the work of the male gatekeepers stationed at the SCNP's booth entrances triggered the drastic decision to replace male gatekeepers with female gatekeepers (Table 2,5.1). This decision was the starting point of an organizationwide strategy focused on (i) boosting women's participation in the management of the SCNP, (ii) providing decent jobs for women, and (iii) providing social support to women in abusive relationships (Int. FF, TM1-7).

Experiences with incidents of moral anger were also associated with attentiveness and relational values of responsibility towards employees, the local community, and the SCNP. For example, the Ceramics Enterprise's founder reported changing the way she established partnerships with external stakeholders in co-creation and brand exposure initiatives after experiences where she judged that the artisan's creative work was misappropriated and misattributed (Table 2, 5.2). Likewise, an employee talked about FUMDHAM's founder's displays of moral anger as incidents that validated the community's concerns about the 
government's neglect and mismanagement of the SCNP, prompting a personal and collective sense of responsibility to raise awareness of such problem: "We also have the same concern [as FUMDHAM's founder]. We went to the streets to protest as well. 'Help us, help us!' We make a living off the park; we need the park. We need to keep telling this history, preserve this heritage that many people don't know yet" (Int. FE1).

Our data analysis showed that expressions of moral anger were highly nuanced, complex, and time- and context-bound. Ceramics Enterprise's founder reported on situations where moral anger led her to act angrily and make hasty decisions with negative consequences to herself and the organization (Int. CF). Informants reported on situations where public statements by FUMDHAM's founder that denounced perceived threats and wrongdoings towards the SCNP had substantial negative consequences to some stakeholders (Int. NE1, 6, 11, 14, 16, 23, 25, 26; Table 2, 5.3). Others remarked on the positive implications of these statements in harnessing public attention to secure financial resources and, consequently, their jobs (Int. TM1-4, 7, NE1, 4, 6, 8). Informants also reported changing their understanding and feelings towards the FUMDHAM's founder displays of moral anger over time (Int. NE1, 6, 13; Table 2, 5.4).

\section{Discussion}

This study set out to identify HRD practices for developing organizational and community capacity in support of sustainability-driven entrepreneurship and broadly explore the supporting role of HRD in deliberate sustainability transformations. We now turn our attention to key aspects of the identified practices that might strengthen such a role and discuss the implications of our findings for research and practice within the fields of entrepreneurship, HRD, and sustainability.

\subsection{Key Aspects of HRD Practice in Support of Sustainability-Driven Entrepreneurship}

Practice 1 foregrounds social-ecological systems thinking in HRD practice. Socialecological systems thinking enables practitioners and scholars to make sense of operating places as configurations of ever-evolving interdependencies-material and symbolicbetween humans and nonhumans [43]. Recognizing reciprocities between organizations, local communities, and local ecosystems may create a foundation for understanding how interactions differ-qualitatively and quantitatively — based on the involvement of different parties, which might facilitate the design of holistic place-based interventions and management of externalities [41,70,71]. Likewise, it may also allow for learning about how interactions and relationships are (or could be) positively or negatively self-reinforcing, which might facilitate the building of a shared vision between stakeholders and the design of strategies to change feedback loops [43]. The importance of a social-ecological systems perspective for the success of sustainable community development and sustainability transformations is well-established in the sustainability literature, especially through approaches that take into account power relations $[3,43]$. However, this is not the case in entrepreneurship and, most notably, HRD literature. In the former, recent studies have theorized about sustainability-driven entrepreneurship as a social-ecological phenomenon, highlighting the importance of social-ecological systems perspective to guide design and implementation choices of sustainable ventures [72]. In the latter, very little attention has been given to nonhumans as more than passive resources instrumental to a goal $[73,74]$.

Practice 2 highlights workforce development and regenerative workforce systems. Consistent with HRD literature, engagement with organizing efforts for workforce development appears to be key to the transformations unfolding in the local community in our case study [75]. Jacobs and Hawley [75] (p. 2543) refer to workforce development as "the coordination of public and private sector policies and programmes that provides individuals with the opportunity for a sustainable livelihood and helps organizations achieve exemplary goals, consistent with the societal context". In our cases, workforce development initiatives manifested through the brokering of institutional arrangements among stakeholders across sectors and jurisdictions to bring about new integrated support services in education, train- 
ing, and employment (including self-employment through enterprise building programs) within and outside the organization. In line with Jacobs and Hawley [75], these integrated support systems were designed to meet the human resource development needs of the organizations and local community and were taken as the basis for building the social infrastructure needed for providing sustainable livelihood opportunities.

Sustainability-oriented entrepreneurial organizations, such as the ones in this case study, adopt overarching goals that foreground whole-system health and wellbeing and strengthen virtuous connectedness with place [15]. These goals represent complementary facets of a regenerative development paradigm that orient organization-wide organizing efforts, including workforce development [39,40]. While the mainstream sustainable development paradigm focuses on achieving development goals today that safeguards the ability of future generations to develop, regenerative development focuses on developing mutually supportive feedbacks between natural and human-made resources that strengthen the capacity to regenerate, rather than degenerate, healthy and flourishing relationships within and between human and natural systems [39]. Under this perspective, organizing regenerative workforce systems is a key factor influencing the ability of SOHOs to promote deliberate sustainability transformations. Yet, we found very little in the literature about what regenerative workforce development looks like in practice, how it can be brought about, and what role it plays in sustainability transformation. Wilkerson and Dake [40] address the former question and propose that regenerative workforce development systems in any industry or sector are founded upon equity, education, entrepreneurship, and employability. Den Boer et al. [76] argue that, to stimulate food system transformation, more attention and efforts need to be focused on competence development that goes beyond tailored professions to focus on actor role(s) in food systems as well as experimentation with and critical reflection on such roles. As defined above, workforce development involves interventions that connect education, employment, and institutional arrangements. Though research on such interventions is still timid in sustainability-driven entrepreneurship and transformation literature, certain topics related to workforce development, including education, competence development, and capacity building, have been recognized as critical levers to societal transformation and extensively studied in community development literature, which offers opportunities for transdisciplinary research synthesis [76-79].

Practice 3 highlights place-based learning as a tool to foster sense of place in individuals and groups. Mounting evidence suggests that a sense of place, i.e., meanings, values, and feelings that people associate with a place, matters to sustainability transformations as it influences people's aspirations as well as the actions they are willing to take $[38,80]$. For example, a strong sense of place can encourage engagement with sustainability-driven entrepreneurship and impact stakeholders' buy-in on entrepreneurial projects for sustainability transformations [81]. Additionally, it can serve as a strong motivation for stewardship attitudes and actions under certain circumstances [38,42,82]. The current study adds to this scholarship by suggesting that integrating educational efforts to foster sense of place with efforts to promote regenerative workforce development might be crucial to the success of entrepreneurial initiatives for sustainable community development in social-ecological contexts characterized by intergenerational poverty, institutional voids, and increasing livelihood vulnerability to environmental degradation. It also corroborates studies that found place to be a powerful resource to support individual and organizational learning and change, including the design of learning interventions in work contexts $[73,74]$. The use of place as a resource for HRD practice is still largely unexplored in literature [73]. We found case study evidence of place being used creatively as a resource in different types of HRD practice, including adult literacy programs, vocational training, on-the-job training, and organizational learning. For example, FUMDHAM's educational and vocational training programs were designed to leverage learning about (content), in (physical space), from (source of experiences), with (experience of collaboration), and for (broader and meaningful purpose) the local place. The same approach was also identified in the work of experienced HRD practitioners engaged in leadership training at the World Heritage Site 
Banff National Park in Canada [73], graduate courses in HRD, and diversity and equity training in organizations [74]. These cases suggest that using place-based learning as a central thread of HRD practice in learning is a promising starting point for HRD scholars to explore ways to enhance HRD's supporting role in sustainability-driven entrepreneurship and organizational change at large.

Practices 4 and 5 highlight embracing conflict and moral anger as resources in HRD practice. Conflicts and moral sentiments, including moral anger, are intrinsic to human relationships $[37,83]$. Yet, both are commonly viewed as undesirable elements in organizing efforts [37]. As defined in this study (see glossary), conflict and moral anger are neither good nor bad per se. It is their outcomes that determine their nature-constructive or detrimental $[83,84]$. Furthermore, conflict and moral anger often stem from or are exacerbated by deeper-rooted social and psychological dynamics between individuals and groups (i.e., social conflicts) that might have little to do with the immediate expressed disagreement and dispute, including identity and sense of belonging, dominance and subordination, status and recognition, dignity and respect, empowerment, and freedom [83].

We found case study evidence of the potential prosocial function of social conflict and moral anger in the development of the studied organizations and communities. This finding is consistent with a growing body of literature in contexts of biodiversity conservation that suggests that social conflicts and moral sentiments can be valuable resources in organizing efforts for transformative changes across societal levels [83]. For example, Moriggi [85] suggests that moral sentiments can fuel tangible emancipatory actions from current deadlocks. In our case, moral anger toward the decade-long mismanagement of the National Park by the governmental agency fueled the impetus and motivation for the creation of a sustainability-driven entrepreneurial organization with high transformational impact in the operating place. Madden and Quinn [83] suggest that a view of conflict as a natural phenomenon that creates a potential for constructive growth may encourage creative change processes that acknowledge, engage, and respond to both immediate presenting conflicts and underlying social conflicts. In our case, conflicts between organizational commitments to women's empowerment and patriarchal gender norms led to the emergence of innovative gender-responsive labor policies and investments that, according to the interviewed female employees, improved current financial conditions of many local women who suffered from severe deprivation and abusive relationships and contributed to positive changes in aspects of social status, social security, dignity, and identity, to name a few.

\subsection{HRD Areas of Engagement in Support of Sustainability Transformations}

Overall, our findings showed that caring —as an alternative way of relating-formed the context for HRD actions associated with learning, organizing, and changing. In our cases, caring manifested as actions associated with relating that were driven by a deep concern for and actionable commitment to the mutual flourishing of human and nonhuman stakeholders and systems. These actions were rooted in care values, including responsibility, reciprocity, stewardship, connectedness, solidarity, and inclusion. In our study, care values were continuously expressed in confessional accounts, public statements, documents, embodied emotions, and actions, as reported in the findings.

Our case study suggests that everyday enactments (sayings, doings, and ways of embodying) of care values in and through HRD practice might contribute to reconfiguring relations between stakeholders (including nonhumans) that are transformative of the individual, organization, community, and social-ecological systems. These findings are in accord with recent sustainability studies indicating that care values embodied in placeshaping practices matter for transformation towards sustainability [38,82,85-87]. In these works, care emerges as both an ethos and tangible practice, i.e., activities "that include everything that we do to maintain, continue, and repair our 'world' so that we can live in it as well as possible" [31] (p. 40). For example, Mehmood [38] showed that the sustainability transformation of a coffee production system in Burundi could be largely 
attributed to local coffee farmers' lived experiences with a specialty coffee company that enacted values of togetherness, dignity, and faith in its everyday practices. In our case study, care values in HRD practice were recognized in actions such as prioritizing the most vulnerable villagers in hiring decisions, paying fair wages, valuing local knowledge and talents, grounding workplace relationships in trust, and being attentive to employees' and the wider community's unmet needs (beyond immediate job requirements). Such actions were transformative for employees who spoke of severe deprivation, helplessness, and indignities in past work. Being exposed to explicit communication of care values (care talk) and treated with dignity and trust in workplace relationships (care practice) changed the very experience of being a worker, local resident, woman, and other personal and community identities. For example, for the women interviewed, being a 'guariteira' (female employees stationed in the entrance gate booths) is not just a job to be executed diligently but, most importantly, is a path towards becoming an empowered and respected woman in the local community.

Foregrounding caring about and for the local place in HRD practice seemed to have been important to the studied SOHOs' engagement with place-based learning and regenerative organizing. The mutually reinforcing relation between care (as ethos and practice) and place-based learning has been theorized and evidenced in numerous studies in the broader sustainability literature [38], particularly environmental education [88]. In contrast, very little is known about the influence of care on organizing practices in organizations and entrepreneurial processes and vice-versa [89]. Our findings suggest that care alongside social-ecological systems thinking seems to contribute to the emergence of organizing efforts to bring about integrated systems with reciprocal feedbacks and interdependencies that regenerate the quality of the relations within human systems and between human beings and nonhuman systems. Muñoz and Branzei [39] (p. 510) termed this process as regenerative organizing and defined it as "sensing and embracing surrounding living ecosystems, aligning organizational knowledge, decision-making, and actions to these systems' structures and dynamics and acting in conjunction, in a way that allows for ecosystems to regenerate, build resilience and sustain life".

Based on our findings and supporting literature, we have upgraded the critical HRD framework by proposing the use of caring, place-based learning, and regenerative organizing - instead of relating, learning, and organizing — as areas of HRD engagement (Figure 1). Like the original, this upgraded framework takes a stakeholder perspective, accounts for power relations, and makes explicit values underpinning practice [28]. Unlike the original, it broadens the notion of stakeholders who participate in and benefit from HRD practice to humans and nonhumans, accounts for human and nonhuman agency in power relations, and privileges place and regenerative workforce systems. For consistency, we expand the original framework's definition of critical HRD to the process of engaging human, organizational, and natural systems that care, learn, organize, and change in ways that promote human interest, organization advancement, and social-ecological impact conducive to regenerative workforce systems.

Incorporating a nonhuman dimension into the CHRD framework is useful in bringing attention to the kinds of relating, learning, organizing, and changing that need to be considered in understanding and analyzing sustainability transformations. This is important because entrepreneurship and HRD research — even more CHRD—tend to be 'oversocialized' and view nature as a monolithic entity. Both fields poorly account for the challenges of governing complexity in human-nonhuman interactions that stem from trade-offs between what is sought to be sustained or developed within ecological systems with nonlinear dynamics as well as social systems with different stakeholders [4]. For example, change efforts targeting a certain pro-environmental behavior might decrease the likelihood of engaging in different pro-environmental behaviors [90]. Global environmental crises such as climate change and the COVID-19 pandemic necessitate approaches that re-privilege the values of nature and humanity together. Likewise, these crises urge society 
to engage in research and practices that are responsive and beneficial to the regenerative sustainability agenda [39].

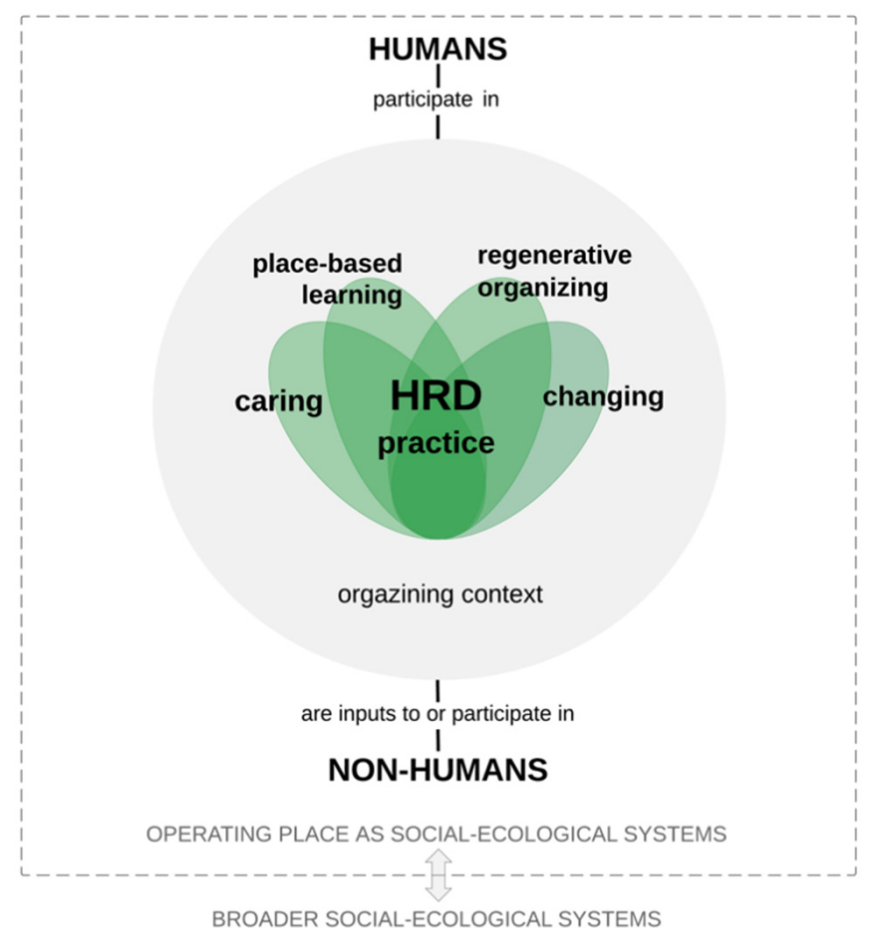

Figure 1. Critical Human Resource Development Framework in support of place-based sustainability transformations.

\subsection{Limitations: A Note of Caution in the Interpretation of the Case Study Findings}

We used a qualitative case study approach to (i) provide a more fine-grained understanding of practices employed by two organizations considered to be illustrative cases of deliberate sustainability transformation in community settings through sustainabilitydriven entrepreneurship and (ii) expand the number and diversity of contexts of such cases in literature. As expected of a qualitative case study methodology, the extent to which the findings can explain phenomena or apply to situations outside and beyond the specific scope of the study is uncertain [63]. We provided rich contextual information of the case study and made available a collection of works about the case study to facilitate the transferability of our findings to others of similar contexts. However, transferability still depends on the readers' experiences and familiarity with the contexts they want to study, which is shaped by their personal and professional backgrounds. Additionally, due to time constraints and secondary data availability, we studied one case (FUMDHAM) with a higher level of detail than the other. While the interventions analyzed are case-specific, we expect that many of the general patterns that contributed to the refinement of the CHRD framework might be applicable across various sustainability-driven entrepreneurship and HRD contexts. This is because some case studies on social- and sustainability-driven entrepreneurial organizations and HRD interventions in social-ecological contexts different from ours have reported on practices representative of these constructs, as discussed above. Considering that the refinements of the framework were based on two cases operating under the same social-ecological context and domain (i.e., natural and cultural heritage conservation), the validity and applicability of the framework deserve further investigation in a larger and more diverse set of cases and domains.

Possible biases exist regarding the sampling approach used for interviews, considering that most of the informants are members of the organizations (or were), relatives of employees, or residents of the two rural villages that have benefited the most from the work of the organizations. Interviewing people with weak ties to the organizations and 
from different rural villages was a challenge for at least two reasons. First, many villagers have worked for the organizations or are close relatives of an employee. Second, the history of social conflicts between the SCNP management and neighboring villagers may bear an impact on who has taken part in the organizations' activities, as well as could be indicated through snowball sampling. Possible biases created by these challenges include a potential overemphasis of the transformative impact of the organization's interventions and possible omissions of their weaknesses in interview data, even though care was taken to critically reflect upon such biases before and during the interview data collection and adjust efforts as much as possible. We also critically reflected upon negative cases and used scholarly works and news media to expand data on negative cases.

Lastly, it is of utmost importance to maintain a critical stance on romanticized depictions of social- and sustainability-driven entrepreneurship as a "force for good" carried out by heroic entrepreneurs. As presented in the Section 4, manifestations of conflict and moral anger in our case study had positive and negative outcomes for the organizations and their stakeholders (humans and nonhumans). Previous studies on moral sentiments, including moral anger, show that displays of moral anger may lead to both ethical and unethical actions in organizations [84]. For example, moral anger can sometimes unleash values of responsibility conducive to sustainability in self and others but also create moral blindspots, scapegoat undeserving individuals or groups, help opportunistic leaders, and enhance negative impacts of conflicts [84]. It was not our aim to examine the net effects of the outcomes of conflicts and moral anger. Yet, this would be valuable to assess context-specific advantages and disadvantages of Practices 4 and 5. In line with previous studies, we claim that critical reflections, nuanced thinking (rather than dichotomous), reflexivity, and ethical rigor are prerequisites to engaging with the identified HRD practices, especially Practices 4 and $5[37,83]$.

\section{Conclusions}

Entrepreneurship revolves around the creative recombination of un- or under-employed resources and capabilities to create new value as well as environments [36]. In this sense, it is reasonable to assume that practices that facilitate the development of individual and organizational capacity are essential to the entrepreneurial process [18]. As a field of practice, HRD can help develop capacity and unleash latent values of human and organizational systems for achieving desirable goals, including those conducive to socially and environmentally responsible behaviors [59]. Our case study suggests that HRD practice can play a crucial supporting role in sustainability-driven entrepreneurship for place-based sustainability transformations when implemented through holistic approaches that foreground caring about and for the quality of the interactions among human, organizational, and natural systems.

We have upgraded the CHRD framework by proposing caring, place-based learning, and regenerative organizing - instead of relating, learning, and organizing —as areas of HRD engagement and highlighting the centrality of place and regenerative workforce systems in HRD practice in support of sustainability transformations. By incorporating these new elements into the CHRD framework and demonstrating its application within the context of sustainability-driven entrepreneurship, we offer original contributions to both HRD and entrepreneurship literature. We advocate that this upgraded framework can be used to support scholars, entrepreneurial actors, and HRD practitioners in navigating the trade-offs and risks associated with developing capacity conducive to sustainability within mainstream institutional logics of organizations and market economies. We call for the application of this upgraded framework as a reflexive tool to enhance transparency in the design and implementation choices in entrepreneurship, HRD, and community development practice for sustainability. Further research could analyze how the identified HRD practices, either individually or together, affect entrepreneurial performance. Future studies could also apply the updated CHRD framework to identify new HRD practices employed by sustainability-driven entrepreneurial organizations with different business 
models as well as within different industries and geographies. Lastly, we encourage fruitful debates and future assessments on its effectiveness for advancing scholarship and practice for sustainability transformations.

Author Contributions: Conceptualization, D.L., A.C.R., S.P.d.C.C.N. and A.A.A.; methodology, D.L., S.P.d.C.C.N. and A.A.A.; validation, D.L., A.C.R., S.P.d.C.C.N. and A.A.A.; formal analysis, D.L., A.C.R. and S.P.d.C.C.N.; data curation, D.L.; writing-original draft preparation, D.L.; writingreview and editing, D.L., A.C.R., S.P.d.C.C.N. and A.A.A.; data visualization, D.L., supervision, A.A.A.; funding acquisition, D.L. and S.P.d.C.C.N. All authors have read and agreed to the published version of the manuscript.

Funding: This research was funded by the Brazilian National Council for Scientific and Technological Development (CNPq, Portuguese: Conselho Nacional de Desenvolvimento Científico e Tecnológico), grant number 409225/20169.

Institutional Review Board Statement: This study was reviewed by the University of Minnesota's research ethics committee (IRB ID STUDY00003018).

Informed Consent Statement: Informed consent was obtained from all interviewees involved in the study.

Data Availability Statement: The data presented in this study are available on request from the corresponding author. Data that are not publicly available due to privacy, ethical, and copyright considerations.

Acknowledgments: We sincerely thank all the interviewees for their considered input and time. We also thank the anonymous reviewers for their valuable comments.

Conflicts of Interest: The authors declare no conflict of interest.

\section{Appendix A}

Table A1. Overview of the Sustainability-Driven Entrepreneurial Organizations.
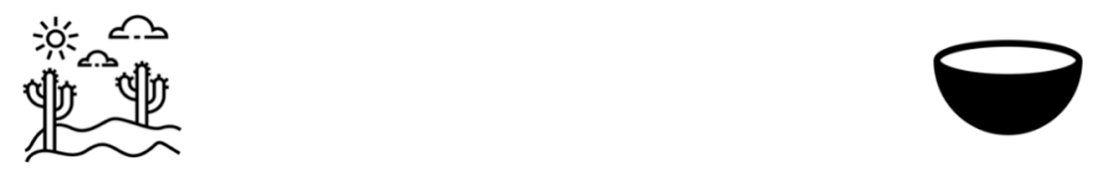

\section{HISTORY}

FUMDHAM is a non-profit, non-governmental organization founded in 1986 by a group of researchers led by a Brazilian female researcher. The group has been engaged in a

French-Brazilian scientific cooperation effort since 1970. The group directed the creation of the Serra da Capivara National Park and World Heritage Site. FUMDHAM was created in response to the rapid degradation of the local ecosystem during the ten years after the SCNP creation due to increasing human disturbances and lack of administrative attention by the responsible governmental authorities. The researchers realized that a formal organization would enable them to mobilize and acquire resources to take care of the SCNP. Additionally, they needed to build a museum locally to store and exhibit the archeological artifacts from the region. FUMDHAM has co-managed the SCNP alongside Brazil's environmental agency since its creation. FUMDHAM's founder has received numerous prestigious national and international awards. She was one of the "1000 PeaceWomen" nominated for the 2005 Nobel Peace Prize.
Ceramics Enterprise is a for-profit small private company legally established in 2005 by a newcomer female entrepreneur. The company started when the entrepreneur bought the Serra da Capivara Ceramic Association, an association co-owned by FUMDHAM and local villagers that was founded in 1994 as part of FUMDHAM's workforce development program. For about ten years, Serra da Capivara Ceramic Association was managed by local villagers with FUMDHAM's support and produced a modest amount of products sold in the local market. However, inadequate business management for the local market conditions (e.g., small consumer demand, geographic isolation) led to poor financial performance. The association was then sold to Ceramics Enterprise's founder, whose entrepreneurial vision involved new production and commercialization processes that allowed for organizational upgrading, better social and economic performance, and financial sustainability. The Ceramics Enterprise was awarded by the Brazilian Business Council for Sustainable Development (CEBDS) - a member of the World Business Council for Sustainable Development (WBCSD Global Network) - as one of the best sustainability project in the country in the small business category. 
Table A1. Cont.

\section{MAIN ACTIVITIES}

Research

Museum

Natural resource management and rock art conservation
Artisan ceramic production

Restaurant

Hostel

Clothing shop

\section{GOVERNANCE, STRUCTURE, AND REVENUE STREAMS}

FUMDHAM is governed by a General Assembly, which nominates an Advisory Board and the Management. The Management consists of a president and two managers (technical-scientific and financial). Whenever needed, FUMDHAM can count on specific technical assistance from different universities both within and outside Brazil. When in good financial standing, FUMDHAM employs approximately 300 people, most of them women from local villages surrounding the Serra da Capivara National Park. The organization has two museums, one research center (laboratories, library, and amphitheater), land, and patents. Revenue comes from public-private partnerships, funded projects, corporate donations, and sales.

Ceramics Enterprise is governed by the founder-owner and two managers (sales and production). The company employs approximately 50 people (women and men) from the local villages. The company has six small ceramic shops, one factory, one restaurant, one hostel, and a clothing shop. Revenue comes from sales (direct sales to tourists and to national and international wholesalers). The company holds certifications of environmental quality standards and fair trade.

\section{Appendix B}

Table A2. Complete Data List.

\begin{tabular}{|c|c|c|c|c|c|}
\hline \multicolumn{6}{|c|}{ INTERVIEW } \\
\hline Alias & Role & Alias & Role & Alias & Role \\
\hline FF & founder, retired & FE13 & staff, operation & NE8 & journalist \\
\hline TM1 & management, current & FE14 & staff, operation & NE9 & staff, civil society organization \\
\hline TM2 & management, current & FE15 & staff, operation & NE10 & $\begin{array}{l}\text { director, civil society } \\
\text { organization }\end{array}$ \\
\hline TM3 & management, past & FE16 & staff, operation & NE11 & tour guide \\
\hline TM4 & management, current & FE17 & staff, operation & NE12 & local business owner \\
\hline TM5 & management, past & FE18 & staff, operation & NE13 & local business owner \\
\hline TM6 & management, past & FE19 & staff, operation & NE14 & community leader \\
\hline TM7 & management, current & FE20 & staff, operation & NE15 & community leader \\
\hline FE1 & staff, operation & $\mathrm{CF}$ & founder & NE16 & local business owner \\
\hline FE2 & staff, operation & CE1 & staff, operations & NE17 & tour guide \\
\hline FE3 & staff, operation & CE2 & staff, operations & NE18 & local business owner \\
\hline FE4 & staff, operation & CE3 & staff, operations & NE19 & local business owner \\
\hline FE5 & staff, operation & CE4 & staff, operations & NE20 & community leader \\
\hline FE6 & staff, operation & NE1 & tour guide & NE21 & teacher \\
\hline FE7 & staff, operation & NE2 & retired & NE22 & local business owner \\
\hline FE8 & staff, operation & NE3 & tour guide & NE23 & researcher \\
\hline FE9 & staff, operation & NE4 & $\begin{array}{l}\text { civil servant, } \\
\text { retired }\end{array}$ & NE24 & civil servant \\
\hline FE10 & staff, operation & NE5 & tour guide & NE25 & local business owner \\
\hline FE11 & staff, operation & NE6 & tour guide & NE26 & community leader \\
\hline FE12 & staff, operation & NE7 & beekeeper & NE27 & researcher \\
\hline
\end{tabular}


Table A2. Cont.

\begin{tabular}{|c|c|}
\hline \multicolumn{2}{|r|}{ ARCHIVES-Organization documents } \\
\hline Alias & Name of document \\
\hline Doc. 1 & Organization strategic plan | 1997 \\
\hline Doc. 2 & Organization marketing plan | 1997 \\
\hline Doc. 3 & Organization project portfolio $\mid 2015$ \\
\hline Doc. 4 & Annual strategic plan | 1998 \\
\hline Doc. 5 & Activity report I 1986-1990 \\
\hline Doc. 6 & Activity report I 1986-1991 \\
\hline Doc. 7 & Activity report I 1990-1995 \\
\hline Doc. 8 & Activity report I 2012 \\
\hline Doc. 9 & Activity report | 2015 \\
\hline Doc. 10 & Activity report $\mid 2012$ \\
\hline Doc. 11 & Annual report | 1991 \\
\hline Doc. 12 & Annual report I 1992 \\
\hline Doc. 13 & Annual report I 1998 \\
\hline Doc. 14 & Annual report I 2007 \\
\hline Doc. 15 & Annual report | 2008 \\
\hline Doc. 16 & Annual report | 2009 \\
\hline Doc. 17 & Annual report | 2010 \\
\hline Doc. 18 & Annual report | 2011 \\
\hline Doc. 19 & Emergency plan for the protection of the Serra da Capivara National I 1991 \\
\hline Doc. 20 & Meeting Minutes of the creation of the Parent Association of the Community Support Center I 1991 \\
\hline Doc. 21 & Project “Integrated Eco-development project in Serra da Capivara National Park" | 1991 \\
\hline Doc. 22 & Project “Integrated Beekeeping Program: honey and other bee products”| 1991 \\
\hline Doc. 23 & Project "Breeding and Sustainable Management of Wildlife" | 1991 \\
\hline Doc. 24 & Project "Creation of the American Man Museum" | 1989-1994 \\
\hline Doc. 25 & Project "Health and the Environment" | 1998 \\
\hline Doc. 26 & Project "Preservation and protection of the Serra da Capivara National Park" | 1991 \\
\hline Doc. 27 & Project “Education" | 1990-1995 \\
\hline Doc. 28 & Project "Piauí" | 1990 \\
\hline Doc. 29 & Project proposal “Museum of the Children” | 1995 \\
\hline Doc. 30 & Project proposal "Inclusion of women in the tourist development of the Serra da Capivara" | 2007 \\
\hline Doc. 31 & Project proposal “Women in Action" | 2005 \\
\hline Doc. 32 & Project proposal "Sanitation and urbanization of the city São Raimundo Nonato, Piauí" | 1992 \\
\hline Doc. 33 & Project proposal “Eco Resort” | 2000-2005 \\
\hline Doc. 34 & Project proposal “Pro-Arte educational program” | 2001 \\
\hline Doc. 35 & Project “ InterArtesII Festival ” | 2004 \\
\hline Doc. 36 & Report "Impact assessment of the socio-economic development programs" | 2002 \\
\hline Doc. 37 & Report “Beekeeping training"| 1996 \\
\hline Doc. 38 & Report “Ceramic production training"| 1996 \\
\hline Doc. 39 & Report “Ceramic production training" $\mid 2000$ \\
\hline Doc. 40 & Report “Recycled paper production training"| 1995 \\
\hline
\end{tabular}


Table A2. Cont.

\begin{tabular}{|c|c|}
\hline Doc. 41 & Report "Recycled paper production training"| 1996 \\
\hline Doc. 42 & Report “Global Art: International Meeting of Rock Art” | 2009 \\
\hline Doc. 43 & Report “Heritage education activities" | 2008 \\
\hline Doc. 44 & Report “InterArtes II Festival” | 2004 \\
\hline Doc. 45 & Report "Co-management activities FUMDHAM/IBAMA" | 2000-2005 \\
\hline Doc. 46 & Report “Community Support Center-Serra Vermelha” | 1995 \\
\hline Doc. 47 & Report "Pro-Arte educational program" | 2005 \\
\hline Doc. 48 & Report “Pro-Arte educational program" | 2004 \\
\hline Doc. 49 & Work Plan “Community Support Center”| 1998 \\
\hline
\end{tabular}

\section{ARCHIVES-News Media and Film documentary}

Alias Title

Nm. 1 Cerâmica Serra da Capivara | 2019| https://www.vivaosertao.com.br/index.php/experiencias/item/173-ceramicaserra-da-capivara\#sigProGalleriac66df6b5d99 (accessed on 14 January 2020).

Arte milenar da cerâmica ganha nova vida por meio do

Nm. 2 artesanato I2011 I https://www.correiobraziliense.com.br/app/noticia/turismo/2011/03/30/interna_turismo,24 5449/arte-milenar-da-ceramica-ganha-nova-vida-por-meio-do-artesanato.shtml (accessed on 4 February 2018).

Nm. 3 Arte pré-histórica do Piauí: cerâmica da Capivara ganha o Mundo I 2009 | https:/ / sebraeartesanato.wordpress.com/ 2009/04/15/arte-pre-historica-do-piaui-ceramica-da-capivara-ganha-o-mundo/ (accessed on 4 February 2018). | 2018 | https:/ / wwW.socialismocriativo.com.br/arte-rupestre-ceramica-da-serra-da-capivara-melhor-projeto-desustentabilidade-do-brasil/ (accessed on 28 July 2019).

Cerâmica Serra Da Capivara Ganha Prêmio De Melhor Projeto Sustentabilidade Do
Nm. 5 Brasil | 2019|https:// fundacaoverde.org.br/pages/cidadesustentavel/2019/06/11/ceramica-serra-da-capivaraganha-premio-de-melhor-projeto-sustentabilidade-do-brasil/ (accessed on 14 January 2020).

\section{Designers Desbravam A Serra Da Capivara, No Piauí, E Descobrem O Poder Do}

Nm. 6 Barro I 2018 Ihttps:/ / casavogue.globo.com/Design/noticia/2018/06/8-designers-famosos-desbravam-serra-dacapivara-no-piaui-e-descobrem-o-poder-do-barro.html (accessed on 14 January 2020).

Serra Da Capivara Ceramics and Relics on Display In Rio I 2017 I https:

Nm. 7 / / agenciabrasil.ebc.com.br/en/cultura/noticia/2017-10/serra-da-capivara-ceramics-and-relics-display-rio (accessed on 4 February 2018).

Coleção Natureza Marca Nova Fase Produtiva Da Cerâmica Serra Da

Nm. 8 Capivara | 2017/http://www.pi.agenciasebrae.com.br/sites/asn/uf/PI/ colecao-natureza-marca-nova-faseprodutiva-da-ceramica-serra-da-capivara,52f66fc3be8ee510VgnVCM1000004c00210aRCRD (accessed on 4 February 2018).

Parque Nacional da Serra da Capivara: Desenho rupestres, visual incrível, e transformação social pela cerâmica | Revista Plurale n.

Nm. 9

37 | 2013 | https: / / www.plurale.com.br/site/revista-digital.php?cod=499\&q=Plurale+em+revista\&bsc=ativar (accessed on 4 February 2018).

Nm. 10

As Figuras Rupestres da Cerâmica Serra da Capivara/Coronel José

Dias-Piauí | 2020 I https: / / www.youtube.com/watch?v=7d0yIOMfj9U (accessed on 1 March 2021).

Nm. 11 Afinidades: Cerâmica Serra da Capivara (Piauí) | 2015 | https:/ / www.youtube.com/watch?v=5MmGIdDo5rI

Nm. 12 Conheça a produção de peças em cerâmica na Serra da

Capivara | 2016 | https: / / www.youtube.com/watch?v=7Duke1-C5Bw (accessed on 4 February 2018).

Nm. 13 Cerâmica e Gastronomia na Serra Da Capivara I 2021 I https: / / www.youtube.com/watch?v=j1Hz9Z4uqlE (accessed on 1 November 2021).

Nm. 14

Rivanildo Feitosa mostra as belezas da cerâmica da Serra da

Capivara | 2012 I https: / / www.youtube.com/watch?v=z3olzDk-a9Y (accessed on 4 February 2018).

Nm. 15 Aliando Empreendedorismo, Sustentabilidade E Melhorias Sociais, Cada Peça Produzida Na Cerâmica Serra Da Capivara | 2020 I https: / / www.facebook.com/watch/?v=171609150887974 (accessed on 1 November 2021). 
Table A2. Cont.

\begin{tabular}{|c|c|}
\hline Nm. 16 & Alistados das Frentes Produtivas Preservam o Meio Ambiente na Serra Da Capivara | 1998 | Informativo Sudene \\
\hline Nm. 17 & Guardiã da Caatinga | 2005 | Criativa \\
\hline Nm. 18 & Niede e a Disneylândia Pré-Histórica \\
\hline Nm. 19 & $\begin{array}{l}\text { Caçadores na Moita: Como Uma Elite Acoberta Caçadores Minando O Patrimônio Ambiental E } \\
\text { Arqueológico I xxxx | Parabólicas }\end{array}$ \\
\hline Nm. 20 & Trabalho de Niede combate a miséria | xxxx | Meio Norte \\
\hline Nm. 21 & $\begin{array}{l}\text { Burocracia brasileira ameaça Patrimônio da Humanidade I } 2015 \text { I https: / /www.swissinfo.ch/por/no-piau\%C3\%AD } \\
\text { burocracia-brasileira-amea\%C3\%A7a-patrim\%C3\%B4nio-da-humanidade/41270422 (accessed on } 4 \text { February 2018). }\end{array}$ \\
\hline Nm. 22 & Indiana Jones da Caatinga | 2005 | Na Poltrona \\
\hline Nm. 23 & Ameaçada, Niede Pede Ajuda A Ministro | 2005 | Cidades \\
\hline Nm. 24 & Funcionários São Demitidos de Parque Mas Ficam Como Voluntários | 2005 | Cidades \\
\hline Nm. 25 & Alvo De Admiração De Ódio | 2004 | O Globo \\
\hline Nm. 26 & Dedicação e Espírito Inovador | 1994 | Jornal do Brasil \\
\hline Nm. 27 & Niede Guidon: Da Biologia Ao Sucesso Da Arqueologia | 1989 | Jornal do Brasil \\
\hline Nm. 28 & $\begin{array}{c}\text { Muito além da pesquisa_com Niède Guidon e } \\
\text { Anne-Marie | 2005 | https: / / oeco.org.br/ reportagens /10927-oeco_11639/ (accessed on } 4 \text { February 2018). } \\
\text { As Vidas Do Parque Nacional Da Serra Da }\end{array}$ \\
\hline
\end{tabular}

Nm. 29 Capivara|2017/ https:/ / oeco.org.br/analises/as-vidas-do-parque-nacional-da-serra-da-capivara/ (accessed on 4 February 2018).

Nm. 30 Capivara 2020 I https:// projetocolabora.com.br/ods11/meio-seculo-de-luta-na-serra-da-capivara/ (accessed on 1 November 2021).

Nm. 31 Entre um Café, uma Prosa com Niède Guidon I 2014 I https:/ / www.youtube.com/watch?v=1-7O1_tD_Oc (accessed on 4 February 2018).

Nm. 32

Entre Nomes João Cláudio Moreno entrevista Niéde

Guidon | 2012 | https: / / www.youtube.com/watch?v=i8ElM0t43MQ (accessed on 4 February 2018).

Nm. 33 Vida de Cientista—Niède Guidon I 2014 I https: / / www.youtube.com/watch?v=LY6kADIdIiU (accessed on 4 February 2018).

Nm. 34 Grandes Mulheres-Niède Guidon I 2011 I https:/ / www.youtube.com/watch?v=a-fWRPAI9Fg (accessed on 4 February 2018).

Nm. 35 Roda viva | 2014 I https: / / www.youtube.com/watch?v=AXa2e5AcU0E (accessed on 4 February 2018).

Nm. 36 Roda viva | 2003 | https:/ / www.youtube.com/watch?v=R1Uu6xjN5nU (accessed on 4 February 2018).

Nm. 37 A História de Niède Guidon / 2019 | https:/ / www.youtube.com/watch?v=CesD6RZ1PiM (accessed on 14 January 2020).

Nm. 38 Niéde Guidon's bluevision | 2019 | https:/ / www.youtube.com/watch?v=c4LwLMhShzI (accessed on 14 January 2020).

Nm. 39 Niede Guidon-Obra Revelada | 2009 | https:/ / www.youtube.com/watch?v=ZxrVDNG6hAI (accessed on 4 February 2018).

Nm. 40 Fronteiras do Olhar Serra da Capivara | 2017 | https:/ / www.youtube.com/watch?v=CQZGLQkh0EE (accessed on 4 February 2018).

Nm. 41 Serra da Capivara-Programa Urbanidades I 2014 I https: / / www.youtube.com/watch?v=dEL_OSTqQXo (accessed on 4 February 2018).

Niède Guidon e as Origens do Homem Americano I

Nm. 42 1990/https://www.youtube.com/watch?v=oX7oToVioC0\&list=PL07B393C6A6B47BF0 (accessed on 4 February 2018).

Nm. 43

Quadro Conversa no Jardim dessa semana entrevista Niede

Guidon I 2008 I https:/ / www.youtube.com/watch?v=_6ho49zNhZc (accessed on 4 February 2018). 
Table A2. Cont.

\begin{tabular}{cc}
\hline Nm. 45 & Entrevista com Niède Guidon-Conversa com Bial | 2019 | Globoplay (accessed on 14 January 2020). \\
\hline Nm. 46 & O Primitivo Tempo Em Que Vivemos | 2018| https://revistarevestres.com.br/entrevista/2962/ (accessed on 14 \\
January 2020).
\end{tabular}

Nm. 47 Ideias | 2014 I https:/ / www.portaldoenvelhecimento.com.br/niede-guidon-arqueologa-de-ideias / (accessed on 4 February 2018).

\begin{tabular}{|c|c|}
\hline Nm. 48 & $\begin{array}{l}\text { A Luta De Niéde Guidon Para Preservar O Maior Tesouro Arqueológico } \\
\text { Brasileiro | 2017 | https:/ / epocanegocios.globo.com/Revista/noticia/2017/10/luta-de-niede-guidon-para- } \\
\text { preservar-o-maior-tesouro-arquelogico-brasileiro.html (accessed on } 4 \text { February 2018). }\end{array}$ \\
\hline Nm. 49 & $\begin{array}{c}\text { Niede Guidon: Arqueologia Com Preocupação } \\
\text { Social | 2007 | https: / / www.camara.leg.br/noticias/102433-niede-guidon-arqueologia-com-preocupacao-social/ } \\
\text { (accessed on } 4 \text { February 2018). }\end{array}$ \\
\hline Nm. 50 & $\begin{array}{c}\text { História Acorrentada I } 2000 \text { l https: / reporterbrasil.org.br/2000/03/historia-acorrentada / (accessed on } \\
\text { 4 February 2018). }\end{array}$ \\
\hline Nm. 51 & $\begin{array}{l}\text { A Saga Empreendedora Da Arqueóloga Niède Guidon Revelou Riquezas Do Piauí I } 2015 \text { I } \\
\text { https:/ / economia.uol.com.br/ultimas-noticias/colunistas/rose-mary-lopes/2015/04/17/a-saga- } \\
\text { empreendedora-da-arqueologa-niede-guidon-revelou-riquezas-do-piaui.htm (accessed on } 4 \text { February 2018). }\end{array}$ \\
\hline Nm. 52 & $\begin{array}{c}\text { O casamento de } \\
\text { Niède | 2008 | https: / / acervo.museudapessoa.org/pt/conteudo/historia/o-casamento-de-niede-44585 (accessed } \\
\text { on } 4 \text { February 2018). }\end{array}$ \\
\hline
\end{tabular}

\section{ARCHIVES-Scholarly works}

Almeida, V. J. R., Justamand, M., \& de Oliveira, G. F. (2021). O Parque Nacional Serra Da Capivara e os seus subsídios para o desenvolvimento do planejamento insurgente na cidade de São Raimundo Nonato-PI. Somanlu: Revista de Estudos Amazônicos, 1(1), 198-218.

\begin{tabular}{|c|c|}
\hline Sw. 2 & $\begin{array}{l}\text { Arruda, M. (1997). Conservação, ecologia humana e sustentabilidade na caatinga: estudo da região do Parque } \\
\text { Nacional da Serra da Capivara (PI). In Caatinga, ecologia humana e degradação Ambiental. Brasília, Brasil: IBAMA. }\end{array}$ \\
\hline Sw. 3 & $\begin{array}{c}\text { Baruzzi, M. C. (2016). The First American Scoop: The Pedra Furada Controversy in Newspapers (1978-2015). } \\
\text { Centaurus, 58(3), 239-256. }\end{array}$ \\
\hline Sw. 4 & $\begin{array}{c}\text { Bastos, S. (2010). O paraíso é no Piauí: a descoberta da arqueóloga Niède Guidon. Teresópolis—RJ, Brazil: Família } \\
\text { Bastos Editora. }\end{array}$ \\
\hline Sw. 5 & $\begin{array}{l}\text { Biancalana, R.N. (2007). Heritage Education in Serra da Capivara National Park-Brazil. In Albert, M. T., Bernecker, } \\
\text { R., Perez, D. G., Thakur, N., Nairen, Z. (Eds), Training Strategies for World Heritage Management (pp. 114-118). } \\
\text { Cottbus, Germany: Druckzone GmbH \& Co. }\end{array}$ \\
\hline Sw. 6 & $\begin{array}{l}\text { Borges, S. E. N. (2007). Invenção do patrimônio mundial: Parque Nacional da Serra da Capivara (Master's thesis, } \\
\text { Universidade Federal do Piauí, Brazil). Retrieved from } \\
\text { http:/ / www.dominiopublico.gov.br/pesquisa/DetalheObraForm.do?select_action=\&co_obra=139998 (accessed } \\
\text { on } 4 \text { February 2018). }\end{array}$ \\
\hline Sw. 7 & $\begin{array}{l}\text { Brandão, C. S., \& Schiavetti, A. (2017). Efetividade da gestão do Parque Nacional Serra da Capivara, Piauí, Brasil: } \\
\text { uma avaliação temporal. Gaia Scientia, 11(2), 32-44. }\end{array}$ \\
\hline Sw. 8 & $\begin{array}{l}\text { Buco, C. D. A. (2014). O caso da Serra da Capivara, vinte anos de socialização do conhecimento através da } \\
\text { arte-educação. Revista Alter Ibi, 1(1),34-45. }\end{array}$ \\
\hline Sw. 9 & $\begin{array}{l}\text { Buco, C., \& Guidon, N. (2009). Serra da Capivara: Cultural Heritage and Socioeconomic Development in the } \\
\text { Northeast. In Oosterbeek, 1., Buonsanto, C. \& Quagliuolo, M. (Eds.), Global Quality Cultural Heritage Management: } \\
\text { Intensive Programme Supporting Texts (26, pp. 1-10). Tomar, Portugal: ARKEOS, CEIPHAR. }\end{array}$ \\
\hline Sw. 10 & $\begin{array}{l}\text { Campos, J. B. R. (2017). Turismo arqueológico e a percepção da comunidade sobre o desenvolvimento local do } \\
\text { município de São Raimundo Nonato/PI (Master's thesis, Universidade de Brasília, Brazil). Retrieved from } \\
\text { https: / / repositorio.unb.br/handle/10482/24682 (accessed on } 4 \text { February 2018). }\end{array}$ \\
\hline Sw. 11 & $\begin{array}{c}\text { Castro, S. G. D. (2004). Os caçadores da Serra da Capivara e face cruel da Educação Ambiental (Master's thesis, } \\
\text { Universidade Federal do Piauí, Brazil). }\end{array}$ \\
\hline
\end{tabular}


Table A2. Cont.

Sw. 12

Castro, S. G. D. (2008). Elogio do Cotidiano: A Educação Ambiental e a Pedagogia Silenciosa da Caatinga no Sertão do Piauí (Doctoral dissertation, Universidade Federal do Ceará, Brazil). Retrieved from https:/ / repositorio.ufc.br/handle/riufc/3507 (accessed on 4 February 2018).

\section{Sw. 13}

Cesario, M. (1996). Contribution of conservation to sustainable living through health promotion. Ambio, 25(1), 39-43.

Sw. 14

Cesario, M. (2004). Health, Environment and Development: human ecological framework. João Pessoa, Brazil: Idéia and EDUFAC.

Sw. 15

Cotes, M., Erler, D. M., Schiavetti, A., \& Vieira do Nascimento, J. (2021). O legado de Niède Guidon no semiárido brasileiro: a percepção de condutores de visitantes do Parque Nacional Serra da Capivara. Antípoda. Revista de Antropología y Arqueología, 42, 179-204.

Sw. 16 Drevillon, E. (2011). Le secret de la roche percée: Niède Guidon. Paris, France: Fayard. Librairie Artheme Fayard.

Sw. 17 Duarte, C. D. S. (2015). A mulher original: produção de sentidos sobre a arqueóloga Niéde Guidon (Master's thesis, Universidade Estadual de Campinas, Brazil).

Sw. 18

Fortes, P. J., \& de Oliveira, J. A. P. (2012). Challenges and opportunities for small businesses in and around Brazilian protected areas. In G. Lohmann \& D. Dredge (Eds.), Tourism in Brazil: Environment, Management and Segments (pp. 77-90). New York, USA: Routledge.

Sw. 19

Furrier, M., \& Oliveira, I. (2018). Clays That Transform Lives: The Ceramic Design Project at Serra Da Capivara Park and Its Importance on Sustainable Development. Paper presented at the Resources for Future Generations, Vancouver, Canada, June 16-21, 2018.

Sw. 20 Gaudêncio, J. S. (2018). Niède Guidon: a cientista brasileira responsável pelo tesouro arqueológico nacional. História da Ciência e Ensino: construindo interfaces, 18, 76-87.

Sw. 21 Godoi, E. P. D. (1993). O trabalho da memoria: um estudo antropológico de ocupação camponesa no sertão do Piaui (Master's thesis, Universidade Estadual de Campinas, Brazil).

Sw. 22 Guidon, N. (2007). Parque Nacional da Serra da Capivara: modelo de preservação do patrimônio arqueológico ameaçado. Revista do Patrimônio Histórico e Artístico Nacional, 33, 75-93.

Sw. 23 Guidon, N. (2007). Parque Nacional Serra da Capivara: sítios rupestres e problemática. FUMDHAMentos, V, 77-108.

Sw. 24 Jordi, J. T. (2009). Turismo arqueológico no Parque Nacional Serra da Capivara (Piauí-Brasil). Brasília, Brazil: IABS editora.

Sw. 25 Levy, C. (2006). Gestão e usos do território: conflitos e práticas sócio-espaciais no Parque Nacional Serra da Capivara, Piauí, Brasil (Master's thesis Universidade Estadual de Campinas, Brazil).

Sw. 26

Luz, C. F. M. (2012). Sítios Arqueológicos de Registro Rupestre: Gestão Compartilhada e as Ações de Preservação do Iphan no Parque Nacional Serra da Capivara e entorno-Piauí, Brasil (Master's thesis, Instituto do Patrimônio Histórico e Artístico Nacional, Brazil).

Sw. 27 Maior, P. M. S. (2020). Retorno Social da Arqueologia: Ações e Projetos da Fumdham nas Comunidades Próximas ao Parque Nacional Serra da Capivara, PI. FUMDHAMentos, XVII (1), 3-31.

Sw. 28 Martin, G., Pessis, A.M. (2020). Entrevista: Niede Guidon. Clio Arqueológica, v.35 (1), pp. 1-13.

Sw. 29 Martins, A. M. F. (2011). Parque Nacional Serra da Capivara: patrimônio cultural da humanidade (Doctoral dissertation, Fundação Getúlio Vargas, Brazil).

Sw. 30

Olmos, F. (1992). Serra da Capivara National Park and the conservation of north-eastern Brazil's caatinga. Oryx, 26(3), 142-146.

Sw. 31

Pessis, A. M., \& Guidon, N. (2007). Serra da Capivara National Park, Brazil: cultural heritage and society. World Archaeology, 39(3), 406-416.

Sw. 32

Pessis, A.M. (2007). Patrimonio e Cidadania. FUMDHAMentos, V, 1-5.

Pessis, A.M., Guidon, N., \& Martin, G. (2012). World Heritage in poverty alleviation: Serra da Capivara National

Sw. 33 Park, Brazil. In A. Galla (Ed.), World Heritage: Benefits beyond borders (pp. 301-311). Cambridge, United Kingdom: Cambridge University Press.

Pires, P. S., Walkowski, M. C., \& Santos, G. S. (2019). A Cerâmica da Serra da Capivara-PI: Sustentabilidade e

Sw. 34 Turismo. In A. P. Portuguez, R. Lanzarini, \& R. J. Santos. (Orgs.), Cultura, Natureza e Saberes na Dinâmica Territoral do Turismo (pp. 308-333). Ituiutaba, Brazil: Barlavento. 
Table A2. Cont.

\begin{tabular}{|c|c|}
\hline Sw. 35 & $\begin{array}{l}\text { Pompa, M. C. (1987). Parque Nacional Serra da Capivara: um drama social. São Raimundo Nonato. } \\
\text { PGAS/UNICAMP, } 1987 .\end{array}$ \\
\hline Sw. 36 & $\begin{array}{l}\text { Ribeiro, A. J. C. B. (2015). O Parque Nacional da Serra da Capivara e a urbanização de São Raimundo Nonato: } \\
\text { transformações socioespaciais no Piauí e suas repercussões no entendimento de sertão (Doctoral dissertation, } \\
\text { Universidade Federal de Pernambuco, Brazil). }\end{array}$ \\
\hline Sw. 37 & $\begin{array}{c}\text { Rodrigues, M. D. S. (2011). Parque Nacional Serra da Capivara e comunidade: Educação, Preservação e Fruição } \\
\text { Social. Um estudo de caso em Coronel José (Master's thesis, Universidade de Trás-os-Montes e Alto } \\
\text { Douro, Portugal). }\end{array}$ \\
\hline Sw. 38 & $\begin{array}{c}\text { Rodrigues, M. H. D. S., Campos, J. B., Oosterbeek, L., Santos, M. C. P., \& Funari, P. P. A. (2021). Território da Serra da } \\
\text { Capivara: um exemplo de sustentabilidade e novos desafios até 2030. In Campos, J. B., Rodrigues, M. H. S. G., } \\
\text { Ladwig, N. I. Ivo, Funari, P. P. A., Oosterbeek, L. (Orgs.), Patrimônio cultural, direito e meio ambiente: arqueologia e } \\
\text { turismo sustentável (pp. 154-173). Criciúma, Brazil: UNESC. }\end{array}$ \\
\hline Sw. 39 & $\begin{array}{l}\text { Silva, C. S. (2019). Patrimônios em Disputa-Conflitos ocasionados no processo de criação do Parque Nacional Serra } \\
\text { da Capivara, Piauí. Revista Historiar, } 11(20), 1-16 .\end{array}$ \\
\hline Sw. 40 & $\begin{array}{l}\text { Silva, P. O. (2016). Responsabilidade socioambiental da Empresa Cerâmica Artesanal Serra da Capivara: análise da } \\
\text { percepção da comunidade local do entorno do Parque Nacional Serra da Capivara (Master's thesis, Universidade } \\
\text { Federal da Bahia, Brazil). }\end{array}$ \\
\hline Sw. 41 & $\begin{array}{l}\text { Sousa, M. S. R. (2011). Deslocamento forçado de posseiros e pequenos proprietários do Parque Nacional da Serra da } \\
\text { Capivara - estratégia de proteção ambiental ou violação de direitos humanos? Revista do Mestrado em Direito, } 5 \text {, } \\
410-429 .\end{array}$ \\
\hline Sw. 42 & $\begin{array}{l}\text { Sousa, M. S. R. D. (2005). Imaginário social de semiárido e o processo de construção de saberes ambientais: o caso do } \\
\text { município de Coronel José Dias-Piauí (Master's thesis, Universidade Federal do Piauí, Brazil). }\end{array}$ \\
\hline Sw. 43 & $\begin{array}{l}\text { Sousa, M. S. R. D. (2009). O povo do Zabelê e o Parque Nacional da Serra da Capivara no Estado do Piauí: tensões, } \\
\text { desafios e riscos da gestão princípio lógica da complexidade constitucional (Doctoral dissertation, Universidade de } \\
\text { Brasília, Brazil). }\end{array}$ \\
\hline Sw. 44 & Swain, T.N. (2012). Niède Guidon, arqueóloga: uma aventura no tempo. \\
\hline Sw. 45 & $\begin{array}{l}\text { UNESCO (2014). Gender equality: heritage and creativity. Paris, France: UNESCO. Available at } \\
\text { https: / / unesdoc.unesco.org/ark:/48223/pf0000229418 (accessed on } 4 \text { February 2018). }\end{array}$ \\
\hline
\end{tabular}

\section{Appendix C}

Table A3. Code List Organized following the Guiding Interrogatives of the Critical HRD Framework [28].
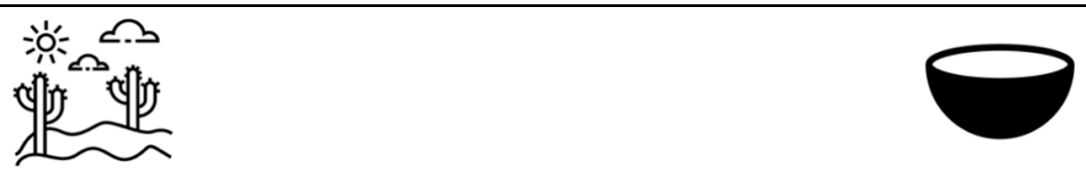

\section{CONTEXT}

What were the situational factors that informed and influenced HRD practice? 
Table A3. Cont.

environmental/spatial factors (droughts, ecological disequilibrium, biodiversity and landscapes, rich archeological heritage, geographical isolation) economic factors (exploitative productive activities, poor market conditions, very poor transport infrastructure, low number of tourists, high unemployment, unskilled workforce, livelihoods inadequate to the local climate)

social factors (extreme poverty, poor access to quality education and healthcare, hunger and malnutrition, seasonal labor migration, gender violence, park-community conflict)

political factors (clientelism and patronage, corruption, bloated bureaucracy, weak governance, impunity for environmental crimes)

cultural factors (rich local cultural knowledge, apathy or negative attitudes towards indigenous culture, frontier mindset of development (nature as an infinite resource)) environmental factors (geographical isolation, droughts, deforestation, biodiversity and landscapes, rich archeological heritage, rural area)

economic factors (exploitative productive activities, poor market conditions, very poor transport infrastructure, low number of tourists, skilled ceramicists, well-structured National Park, ceramic community association with rudimentary production and environmental certifications) social factors (extreme poverty, gender violence, park-community conflict)

political factors (bloated bureaucracy, corruption, weak governance)

cultural factors (rich local cultural knowledge)

\section{STAKEHOLDERS}

Whom did HRD practice serve? Who participated in HRD practice?

\section{FUMDHAM}

employees

local villagers

students (local to international)

researchers and universities (local to international)

tourists

SCNP, wildlife, rock paintings

local companies

donors

funding agencies

governments and agencies (local to international)

UNESCO

prehistoric generations

future generations

\author{
Ceramics Enterprise \\ employees \\ local villagers \\ students (local to international) \\ tourists \\ SCNP, wildlife, rock paintings \\ non-local wholesalers (other states and countries) \\ governments and agencies (local to national) \\ FUMDHAM \\ designers
}

\section{VALUES AND ASSUMPTIONS}

What were the values and assumptions underpinning HRD practice?

holistic, "whole person" approach

multiple values of natural and cultural heritage (instrumental,

intrinsic, symbolic)

responsibility to care for the local place (nature, cultural heritage, and

local community)

stewardship towards nature and community

reciprocity towards the local community and nature

solidarity towards nonhumans

solidarity towards prehistoric and future generations

long-term commitment to the organizational mission

commitment to social inclusion and empowerment of the most

vulnerable groups

work ethics

transdisciplinarity

participation and collaboration

scientific knowledge informs decisions

embeddedness in place

holistic, "whole person" approach

multiple values of natural and cultural heritage

(instrumental, intrinsic, symbolic)

responsibility to care for the local place (nature,

cultural heritage, and local community)

stewardship towards nature and community

kinship

reciprocity towards community and nature

long-term commitment to the organizational

mission

commitment to social inclusion and

empowerment of the most vulnerable groups

work ethics

embeddedness in place

local knowledge

local knowledge 
Table A3. Cont.

\section{METHODS}

How was HRD practice implemented?

\section{Individual learning and development}

Educational and vocational training programs that raised awareness of (i) livelihood vulnerabilities associated with the degradation of the SCNP and (ii) opportunities to sustainable livelihoods

Training and development of local villagers in teaching and healthcare Training and development of local villagers in occupations related to tourism, hospitality, arts, research, sustainable agriculture, ceramics, and handicraft Training and development accounted for and valued individual's prior knowledge and talent

Training and development integrated technical and moral competencies conducive to responsible environmental behaviors

Schooling for children, youth, and adults of the local villages

Pedagogy focused on fostering sense of place, stewardship, and values of responsibility

Contextualized educational curriculum centered on environmental education and arts

Organizing local seminars and workshops about gender violence and environmental issues

\section{Organization development and change}

Planning and design processes considered social dilemmas, cognitive limitations, and cultural predispositions

Design of core organizational strategies accounted for basic unmet needs of the local community, including basic infrastructure, education, and healthcare Design of core organizational strategies accounted for short- and long-term sustainability goals

Organizing new institutional arrangements across sectors and scales to create opportunities for new careers and jobs in science, hospitality, and tourism Supporting the creation of community-based and social enterprises locally Design and implementation of a gender-responsive labor organizational policy Organizing a supportive network for battered female employees

Design and implementation of selection and hiring strategies that accounted for individuals' work ethics, social vulnerability, and attitudes related to environmental responsibility

Creating social contracts with workers concerning commitment to pro-environmental behaviors

Restructuring the organization during critical financial crisis through a humanistic approach-upholding social contacts took precedence over sustaining economic capital or rents

Engaging in, organizing, and supporting participatory spaces regarding the governance of the SCNP

Using action research

Supporting the development of transdisciplinary research in the SCNP region

Leadership served as a role model of perseverance and dedication to a sustainability mission

Organizing formal and informal opportunities for social learning for employees and external stakeholders (including tourists, designers, researchers, students)

Designing and implementing innovative and unconventional strategies (defiant of cultural norms and business as usual practices) to bring about and sustain sustainability goals

Engaging in employee advocacy

Engagement with media and science communication to inform local, regional, national, and global audiences about the organization's purpose,

commitments, and work
Individual learning and development

Training in ceramic production, drawing, customer service skills

Training and development accounted for and valued individual's prior knowledge and talent

Organization development and change Planning and design processes considered social dilemmas, cognitive limitations, and cultural predispositions Design of core organizational strategies accounted for short- and long-term sustainability goals Design and implementation of a gender-responsive labor policy Designing and implementing organizational strategies for profit-sharing and shared ownership with employees Leadership served as a role model of perseverance and dedication to a sustainability mission

Engaging in employee advocacy Organizing formal and informal opportunities for social learning for employees and external stakeholders

Design and implementation of selection and hiring strategies that accounted for individuals' work ethics, social vulnerability, and attitudes related to environmental responsibility Creating social contracts with workers concerning commitment to pro-environmental behaviors Restructuring the organization during critical financial crisis through a humanistic approach-upholding social contacts took precedence over sustaining economic capital or rents

Designing and implementing unconventional strategies (defiant of cultural norms and business as usual practices) to bring about and sustain sustainability goals

Organizing partnerships with external stakeholders for brand exposure Partnering with FUMDHAM and external organizations to deliver professional development training to employees Engagement with media to inform local, regional, and national audiences about the organization's purpose, commitments, and work 


\section{References}

1. Díaz, S.; Settele, J.; Brondízio, E.S.; Ngo, H.T.; Agard, J.; Arneth, A.; Balvanera, P.; Brauman, K.A.; Butchart, S.H.M.; Chan, K.M.A.; et al. Pervasive human-driven decline of life on Earth points to the need for transformative change. Science 2019, 366, eaax3100. [CrossRef] [PubMed]

2. Fedele, G.; Donatti, C.I.; Harvey, C.A.; Hannah, L.; Hole, D.G. Transformative adaptation to climate change for sustainable social-ecological systems. Environ. Sci. Policy 2019, 101, 116-125. [CrossRef]

3. Bennett, N.J.; Blythe, J.; Cisneros-Montemayor, A.M.; Singh, G.G.; Sumaila, U.R. Just transformations to sustainability. Sustainability 2019, 11, 3881. [CrossRef]

4. $\quad$ Patterson, J.; Schulz, K.; Vervoort, J.; van der Hel, S.; Widerberg, O.; Adler, C.; Hurlbert, M.; Anderton, K.; Sethi, M.; Barau, A. Exploring the governance and politics of transformations towards sustainability. Environ. Innov. Soc. Transit. 2017, 24, 1-16. [CrossRef]

5. O'Brien, K. Global environmental change II: From adaptation to deliberate transformation. Prog. Hum. Geogr. 2011, 36, 667-676. [CrossRef]

6. Parrish, B.D. Sustainability-driven entrepreneurship: Principles of organization design. J. Bus. Ventur. 2010, 25, 510-523. [CrossRef]

7. Parrish, B.D.; Foxon, T.J. Sustainability entrepreneurship and equitable transitions to a low-carbon economy. Greener Manag. Int. 2006, 2006, 47-62. [CrossRef]

8. Hörisch, J. The Role of Sustainable Entrepreneurship in Sustainability Transitions: A Conceptual Synthesis against the Background of the Multi-Level Perspective. Adm. Sci. 2015, 5, 286-300. [CrossRef]

9. Schaltegger, S.; Beckmann, M.; Hockerts, K. Sustainable entrepreneurship: Creating environmental solutions in light of planetary boundaries. Int. J. Entrep. Ventur. 2018, 10, 1-16. [CrossRef]

10. Schaefer, K.; Corner, P.D.; Kearins, K. Social, Environmental and Sustainable Entrepreneurship Research: What Is Needed for Sustainability-as-Flourishing? Organ. Environ. 2015, 28, 394-413. [CrossRef]

11. Hummels, H.; Argyrou, A. Planetary demands: Redefining sustainable development and sustainable entrepreneurship. J. Clean. Prod. 2021, 278, 123804. [CrossRef]

12. Meglio, O.; Di Paola, N. Innovation and entrepreneurship for well-being and sustainability. Sustainability 2021, 13, 9154. [CrossRef]

13. Alvord, S.H.; Brown, L.D.; Letts, C.W. Social Entrepreneurship and Societal Transformation: An Exploratory Study. J. Appl. Behav. Sci. 2004, 40, 260-282. [CrossRef]

14. Parrish, B.D. Sustainability Entrepreneurship: Design Principles, Processes, and Paradigms. Ph.D. Thesis, University of Leeds, Leeds, UK, 2007; 308p.

15. Hestad, D.; Tàbara, J.D.; Thornton, T.F. The three logics of sustainability-oriented hybrid organisations: A multi-disciplinary review. Sustain. Sci. 2021, 16, 647-661. [CrossRef]

16. Ziegler, R.; Balzac-Arroyo, J.; Hölsgens, R.; Holzgreve, S.; Lyon, F.; Spangenberg, J.H.; Thapa, P.P. Social innovation for biodiversity: A literature review and research challenges. Ecol. Econ. 2022, 193, 107336. [CrossRef]

17. Gray, B.J.; Duncan, S.; Kirkwood, J.; Walton, S. Encouraging sustainable entrepreneurship in climate-threatened communities: A Samoan case study. Entrep. Reg. Dev. 2014, 26, 401-430. [CrossRef]

18. Middlemiss, L.; Parrish, B.D. Building capacity for low-carbon communities: The role of grassroots initiatives. Energy Policy 2010, 38, 7559-7566. [CrossRef]

19. Biggs, R.; Westley, F.R.; Carpenter, S.R. Navigating the back loop: Fostering social innovation and transformation in ecosystem management. Ecol. Soc. 2010, 15, 9. [CrossRef]

20. Hestad, D.; Tàbara, J.D.; Thornton, T.F. The role of sustainability-oriented hybrid organisations in the development of transformative capacities: The case of Barcelona. Cities 2021, 119, 103365. [CrossRef]

21. Hübel, C. Entrepreneurship-driven organizational transformation for sustainability: A sensemaking lens. J. Organ. Chang. Manag. 2022, 35, 240-256. [CrossRef]

22. McGuire, D. Foundations of human resource development. In Human Resource Development: Theory and Practice; McGuire, D., Jorgensen, K.M., Eds.; SAGE: London, UK, 2011; pp. 1-11. ISBN 9781450349185.

23. Chan, K.M.A.; Boyd, D.R.; Gould, R.K.; Jetzkowitz, J.; Liu, J.; Muraca, B.; Naidoo, R.; Olmsted, P.; Satterfield, T.; Selomane, O.; et al. Levers and leverage points for pathways to sustainability. People Nat. 2020, 2, 693-717. [CrossRef]

24. Ardichvili, A. The Role of HRD in CSR, Sustainability, and Ethics: A Relational Model. Hum. Resour. Dev. Rev. 2013, 12, 456-473. [CrossRef]

25. Scully-Russ, E. Human resource development and sustainability: Beyond sustainable organizations. Hum. Resour. Dev. Int. 2012, 15, 399-415. [CrossRef]

26. Garavan, T.N.; McGuire, D. Human resource development and society: Human resource development's role in embedding corporate social responsibility, sustainability, and ethics in organizations. Adv. Dev. Hum. Resour. 2010, 12, 487-507. [CrossRef]

27. McGuire, D.; Cross, C.; O'Donnell, D. Why humanistic approaches in HRD won't work. Hum. Resour. Dev. Q. 2005, 16, 131-137. [CrossRef]

28. Bierema, L.; Callahan, J.L. Transforming HRD: A Framework for Critical HRD Practice. Adv. Dev. Hum. Resour. 2014, 16, 429-444. [CrossRef] 
29. Nelson, D.R.; Finan, T.J. Praying for drought: Persistent vulnerability and the politics of patronage in Ceará, Northeast Brazil. Am. Anthropol. 2009, 111, 302-316. [CrossRef]

30. Vieira, R.M.d.S.P.; Sestini, M.F.; Tomasella, J.; Marchezini, V.; Pereira, G.R.; Barbosa, A.A.; Santos, F.C.; Rodriguez, D.A.; do Nascimento, F.R.; Santana, M.O.; et al. Characterizing spatio-temporal patterns of social vulnerability to droughts, degradation and desertification in the Brazilian northeast. Environ. Sustain. Indic. 2020, 5, 100016. [CrossRef]

31. Tronto, J.C. Caring Democracy; New York University Press: New York, NY, USA, 2013; ISBN 0814770452.

32. Moriggi, A.; Soini, K.; Bock, B.B.; Roep, D. Caring in, for, and with nature: An integrative framework to understand green care practices. Sustainability 2020, 12, 3361. [CrossRef]

33. LeBaron, M.; Pillay, V. Conflict Across Cultures; Intercultural Press: London, UK, 2006; ISBN 1931930228.

34. Peterson, M.N.; Peterson, M.J.; Peterson, T.R.; Leong, K. Why transforming biodiversity conservation conflict is essential and how to begin. Pac. Conserv. Biol. 2013, 19, 94-103. [CrossRef]

35. O'Brien, K.; Sygna, L. Responding to climate change: The three spheres of transformation. In Proceedings of the Transformation in a Changing Climate, Oslo, Norway, 19-21 June 2013; pp. 16-23.

36. Ardichvili, A.; Cardozo, R.; Ray, S. A theory of entrepreneurial opportunity identification and development. J. Bus. Ventur. 2003, 18, 105-123. [CrossRef]

37. Lindebaum, D.; Geddes, D. The place and role of (moral) anger in organizational behavior studies. J. Organ. Behav. 2016, 37, 738-757. [CrossRef] [PubMed]

38. Mehmood, A.; Marsden, T.; Taherzadeh, A.; Axinte, L.F.; Rebelo, C. Transformative roles of people and places: Learning, experiencing, and regenerative action through social innovation. Sustain. Sci. 2020, 15, 455-466. [CrossRef]

39. Muñoz, P.; Branzei, O. Regenerative Organizations: Introduction to the Special Issue. Organ. Environ. 2021, 34, 507-516. [CrossRef]

40. Wilkerson, E.A.; Dake, A. Workforce development: A regenerative perspective. In Regenerative Urban Development, Climate Change and the Common Good; Caniglia, B.S., Frank, B., Knott, J.L., Sagendorf, K.S., Wilkerson, E.A., Eds.; Routledge: London, UK, 2019; pp. 226-239. [CrossRef]

41. West, S.; Haider, L.J.; Stålhammar, S.; Woroniecki, S. A relational turn for sustainability science? Relational thinking, leverage points and transformations. Ecosyst. People 2020, 16, 304-325. [CrossRef]

42. Chapin, F.S.; Knapp, C.N. Sense of place: A process for identifying and negotiating potentially contested visions of sustainability. Environ. Sci. Policy 2015, 53, 38-46. [CrossRef]

43. Berkes, F.; Folke, C. Linking Social and Ecological Systems: Management Practices and Social Mechanisms for Building Resilience; Cambridge University Press: Cambridge, UK, 1998; ISBN 0521785626.

44. O'Brien, $\mathrm{K}$. Is the $1.5^{\circ} \mathrm{C}$ target possible? Exploring the three spheres of transformation. Curr. Opin. Environ. Sustain. 2018, 31, 153-160. [CrossRef]

45. Scoones, I.; Stirling, A.; Abrol, D.; Atela, J.; Charli-Joseph, L.; Eakin, H.; Ely, A.; Olsson, P.; Pereira, L.; Priya, R.; et al. Transformations to sustainability: Combining structural, systemic and enabling approaches. Curr. Opin. Environ. Sustain. 2020, 42, 65-75. [CrossRef]

46. Rahdari, A.; Sepasi, S.; Moradi, M. Achieving sustainability through Schumpeterian social entrepreneurship: The role of social enterprises. J. Clean. Prod. 2016, 137, 347-360. [CrossRef]

47. York, J.G.; Venkataraman, S. The entrepreneur-environment nexus: Uncertainty, innovation, and allocation. J. Bus. Ventur. 2010, 25, 449-463. [CrossRef]

48. Hestad, D.; Tàbara, J.D.; Thornton, T.F. Transcending unsustainable dichotomies in management: Lessons from SustainabilityOriented Hybrid Organisations in Barcelona. J. Clean. Prod. 2020, 244, 118766. [CrossRef]

49. Pauceanu, A.M.; Rabie, N.; Moustafa, A.; Jiroveanu, D.C. Entrepreneurial leadership and sustainable development-A systematic literature review. Sustainability 2021, 13, 11695. [CrossRef]

50. Zarestky, J.; Collins, J.C. Supporting the United Nations' 2030 sustainable development goals: A call for international HRD action. Hum. Resour. Dev. Int. 2017, 20, 371-381. [CrossRef]

51. Kim, N. Toward the Use of Human Resource Development for Societal Development: Issues, Challenges, and Opportunities. Adv. Dev. Hum. Resour. 2012, 14, 345-354. [CrossRef]

52. Henderson, G.M. Transformative Learning as a Condition for Transformational Change in Organizations. Hum. Resour. Dev. Rev. 2002, 1, 186-214. [CrossRef]

53. McLean, G.N.; Kuo, M.H.; Budhwani, N.N.; Yamnill, S.; Virakul, B. Capacity Building for Societal Development: Case Studies in Human Resource Development. Adv. Dev. Hum. Resour. 2012, 14, 251-263. [CrossRef]

54. Wang, J. HRD for Societal Development. Adv. Dev. Hum. Resour. 2012, 14, 305-317. [CrossRef]

55. Benton-Short, L.; Cseh, M. Changing Cities, Changing Culture: The Challenges and Opportunities for HRD in Urban Sustainability. Adv. Dev. Hum. Resour. 2015, 17, 460-472. [CrossRef]

56. Sadler-Smith, E. Communicating Climate Change Risk and Enabling Pro-Environmental Behavioral Change Through Human Resource Development. Adv. Dev. Hum. Resour. 2015, 17, 442-459. [CrossRef]

57. Haddock, J.; Jeffrey, J.; Miles, D.; Muller-Camen, M.; Hartog, M. Green HRD: The Potential Contribution of HRD Concepts and Theories to Environmental Management. In Proceedings of the 11th International Conference on Human Resource Development Research and Practice across Europe, Pécs, Hungary, 2-4 June 2010; pp. 1-18. 
58. Baek, P.; Kim, N. Exploring a theoretical foundation for HRD in society: Toward a model of stakeholder-based HRD. Hum. Resour. Dev. Int. 2014, 17, 499-513. [CrossRef]

59. Ardichvili, A. Sustainability of nations, communities, organizations and individuals: The role of HRD. Hum. Resour. Dev. Int. 2011, 14, 371-374. [CrossRef]

60. Kuchinke, K.P. Human development as a central goal for human resource development. Hum. Resour. Dev. Int. 2010, 13, 575-585. [CrossRef]

61. Fenwick, T. Conceptualizing Critical HRD (CHRD): Tensions, dilemmas and possibilities. In The Routledge Companion to Human Resource Development; Poell, R.F., Rocco, T.S., Roth, G.L., Eds.; Taylor \& Francis: London, UK, 2014; pp. 113-123.

62. Fenwick, T.J. Toward a critical HRD in theory and practice. Adult Educ. Q. 2004, 54, 193-209. [CrossRef]

63. Yazan, B. Three Approaches to Case Study Methods in Education: Yin, Merriam, and Stake. Qual. Rep. 2015, 20, 134-152. [CrossRef]

64. Stake, R.E. The Art of Case Study Research; SAGE: Thousand Oaks, CA, USA, 1995; ISBN 080395767X.

65. Pessis, A.M.; Martin, G.; Guidon, N. World heritage in poverty alleviation: Serra da Capivara National Park, Brazil. In World Heritage: Benefits Beyond Borders; Galla, A., Ed.; Cambridge University Press: Cambridge, UK, 2012; pp. 301-311. [CrossRef]

66. Cesario, M. Contribution of conservation to sustainable living through health promotion. Ambio 1996, 25, 39-43. [CrossRef]

67. Da Silva, J.M.C.; Leal, I.R.; Tabarelli, M. (Eds.) Caatinga: The Largest Tropical Dry Forest Region in South America; Springer International Publishing: Cham, Switzerland, 2017; ISBN 978-3-319-68338-6.

68. Fortes, P.J.d.O.C.; Puppim de Oliveira, J.A. Challenges and Opportunities for Small Businesses in and around Brazilian. In Tourism in Brazil: Environment, Management and Segments; Lohmann, G., Dredge, D., Eds.; Routledge: London, UK, 2012 ; pp. 77-90.

69. Braun, V.; Clarke, V. Reflecting on reflexive thematic analysis. Qual. Res. Sport Exerc. Health 2019, 11, 589-597. [CrossRef]

70. Schlaile, M.P.; Urmetzer, S.; Ehrenberger, M.B.; Brewer, J. Systems entrepreneurship: A conceptual substantiation of a novel entrepreneurial "species". Sustain. Sci. 2021, 16, 781-794. [CrossRef]

71. Romero-Castro, N.; Miramontes-Viña, V.; López-Cabarcos, M.Á. Understanding the Antecedents of Entrepreneurship and Renewable Energies to Promote the Development of Community Renewable Energy in Rural Areas. Sustainability 2022, 14, 1234. [CrossRef]

72. Muñoz, P.; Cohen, B. Towards a social-ecological understanding of sustainable venturing. J. Bus. Ventur. Insights 2017, 7, 1-8. [CrossRef]

73. Nissley, N. The power of place in human resource development: An invitation to explore the link between learning and location Hum. Resour. Dev. Q. 2011, 22, 545-555. [CrossRef]

74. Hardy, G.; Newsham, C. Place: A (re)source for learning. In Critical Thinking in Human Resource Development; Elliott, C., Turnbull, S., Eds.; Routledge: London, UK, 2005; pp. 96-104.

75. Jacobs, R.L.; Hawley, J.D. The Emergence of 'Workforce Development': Definition, Conceptual Boundaries and Implications In International Handbook of Education for the Changing World of Work; Maclean, R., Wilson, D., Eds.; Springer: Dordrecht, The Netherlands, 2009; pp. 2537-2552. ISBN 978-1-4020-5280-4.

76. Den Boer, A.C.; Broerse, J.E.; Regeer, B.J. The need for capacity building to accelerate food system transformation. Curr. Opin. Food Sci. 2021, 42, 119-126. [CrossRef]

77. Chan, K.Y.; Ho, M.R.; Chernyshenko, O.S.; Bedford, O.; Uy, M.A.; Gomulya, D.; Sam, Y.L.; Phan, W.M.J. Entrepreneurship, professionalism, leadership: A framework and measure for understanding boundaryless careers. J. Vocat. Behav. 2012, 81, 73-88. [CrossRef]

78. O'Brien, K.; Reams, J.; Caspari, A.; Dugmore, A.; Faghihimani, M.; Fazey, I.; Hackmann, H.; Manuel-Navarrete, D.; Marks, J.; Miller, R.; et al. You say you want a revolution? Transforming education and capacity building in response to global change. Environ. Sci. Policy 2013, 28, 48-59. [CrossRef]

79. Diepolder, C.S.; Weitzel, H.; Huwer, J. Competence frameworks of sustainable entrepreneurship: A systematic review. Sustainability 2021, 13, 13734. [CrossRef]

80. Peris-Blanes, J.; Segura-Calero, S.; Sarabia, N.; Ribó-Pérez, D. The role of place in shaping urban transformative capacity. The case of València (Spain). Environ. Innov. Soc. Transit. 2022, 42, 124-137. [CrossRef]

81. Süsser, D.; Döring, M.; Ratter, B.M.W. Harvesting energy: Place and local entrepreneurship in community-based renewable energy transition. Energy Policy 2017, 101, 332-341. [CrossRef]

82. Grenni, S.; Soini, K.; Horlings, L.G. The inner dimension of sustainability transformation: How sense of place and values can support sustainable place-shaping. Sustain. Sci. 2020, 15, 411-422. [CrossRef]

83. Madden, F.; McQuinn, B. Conservation's blind spot: The case for conflict transformation in wildlife conservation. Biol. Conserv. 2014, 178, 97-106. [CrossRef]

84. Lindebaum, D.; Geddes, D.; Gabriel, Y. Moral Emotions and Ethics in Organisations: Introduction to the Special Issue. J. Bus. Ethics 2017, 141, 645-656. [CrossRef]

85. Moriggi, A.; Soini, K.; Franklin, A.; Roep, D. A Care-Based Approach to Transformative Change: Ethically-Informed Practices, Relational Response-Ability \& Emotional Awareness. Ethics Policy Environ. 2020, 23, 281-298. [CrossRef]

86. West, S.; Haider, L.J.; Masterson, V.; Enqvist, J.P.; Svedin, U.; Tengö, M. Stewardship, care and relational values. Curr. Opin. Environ. Sustain. 2018, 35, 30-38. [CrossRef] 
87. Rosenberg, M.N. What matters? The role of values in transformations toward sustainability: A case study of coffee production in Burundi. Sustain. Sci. 2021, 1-12. [CrossRef]

88. dos Santos, N.B.; Gould, R.K. Can relational values be developed and changed? Investigating relational values in the environmental education literature. Curr. Opin. Environ. Sustain. 2018, 35, 124-131. [CrossRef]

89. Fors, P.; Lennerfors, T.T. The individual-care nexus: A theory of entrepreneurial care for sustainable entrepreneurship. Sustainability 2019, 11, 4904. [CrossRef]

90. Truelove, H.B.; Carrico, A.R.; Weber, E.U.; Raimi, K.T.; Vandenbergh, M.P. Positive and negative spillover of pro-environmental behavior: An integrative review and theoretical framework. Glob. Environ. Chang. 2014, 29, 127-138. [CrossRef] 